\title{
Products Liability
}

\author{
Part II \\ The Protection of the Producing Enterprise ${ }^{1}$
}

\author{
Richard G. Wilson* \\ I \\ TYPICAIITY OF RISK
}

Within a society that has no universal and comprehensive social insurance for all injuries, a law of products liability must balance the twin objectives of achieving minimum legitimate compensation (or loss distribution) and of achieving mininum conditions under which the enterprise can perform its service to the community. Manufacturers are not expected to subsidize every act of carelessness on the part of consumers, nor compensate for every injury remotely connected with the use of a product.

It has been seen in the first part of this paper that the range of liability is in process of extension to the ultimate consumer or user at one end and to the dominant (possibly to every) unit in the marketing chain at the other end. Within this range of liability, limitations are imposed. As yet these limitations are far from crystallized. Certain patterns, however, seem to be emerging. Some are traditional because common law experience has provided analogies; some are new because the problem has not precisely occurred before. The criterion which has arisen may be usefully formulated as typicality of risk. Only those risks which are typical, reasonable, normally expectable, are to be thrown upon the enterprise (and via the enterprise, in all but the rarest of cases, upon the consuming public) instead of upon the individual. This is substantially an objectivised reformulation of the foreseeability test of negligence. It is within this framework that the categories of enterprise protection will be tentatively laid out as far as they can be detected. It seems that the requirenients of typicality of risk are sixfold: (1) defectiveness in law; (2) defectiveness in fact; (3) defectiveness at the time of leaving the enterprise; (4) reasonable handling by intermediate third parties; (5) reasonable use by the consumer or user plaintiff; and (6) typical mjury.

* B.C.L. Oxford University, 1952 ; LL.M. University of California School of Law, Berkeley, 1953.

1 Part I of this article, The Protection of the Injured Person, appeared at 43 CaLIP. L. REv. 614 (1955). 
A.

\section{Defectiveness In Law.}

It is, of course, an expository device to assume that injury from nondefective products is noncompensable. Such a device is here adopted in order to facilitate discussion and analysis of causation-in-fact problems. ${ }^{2}$

Whether a product is defective is often sufficiently obvious. Particles of glass in bread patently make it unfit to eat, and the same goes for most foreign substances in food. ${ }^{3}$ A "brash" ladder rung,, a cracked chair leg, and a lumbering tool made of porous steel containing blowholes ${ }^{0}$ pretty clearly are articles that are unfit for their normal and intended purposes. There are more difficult cases: Llewellyn thus defines "defect":?

The term is intended to be broad enough to include defects of manufacture or design, adulteration, presence of foreign substances, and indeed the whole range of hidden danger, when the net product appears and ought to be safe to use in the ordinary manner but is not.

The wide scope for policy judgments is shown by the use of such words as "appears," "ought to," and "ordinary." Is an automobile that lacks shatterproof glass defective? ${ }^{8}$ Is an electric pipe that cannot support the weight of a ladder defective? ${ }^{9}$ What about a chair that collapses when it is stood upon ${ }^{10}$ Some of these questions could be formulated in terms of liability for normal reasonable use, or for normal reasonable reliance. How safe should a lawn mower be ${ }^{11} A$ chaise longue $?^{12} A$ vaporizer $~^{13} A$ hay baler $?^{14}$ A tire tube vulcanizing machine ${ }^{15}$ Ready-mix cement? ${ }^{10}$ A rug? ${ }^{17}$ An

2 See generally on the analysis of causation Prosser, TorTs 218-23 (2d ed. 1955).

3 Dryden v. Continental Baking Co., 11 Cal.2d 33, 77 P.2d 833 (1938). Is a tack in a Coca Cola hottle a defect (does it make it unfit for human consumption)? Yes, Foley v. Cola Cola Bottling Co., 215 S.W.2d 314 (Mo. App. 1948). Is a worm which is not proved poisonous in a can of beans a defect? No, Alma Canning Co. v. Rorie, 216 Ark. 444, 226 S.W.2d 64 (1950). Is a hairpin in Coca Cola a defect? No, Jonesboro Coca Cola Bottling Co. v. Hambrooke, 206 Ark. 385, 175 S.W.2d 387 (1943).

4 Kalash v. Los Angeles Ladder Co., 1 Cal.2d 229, 34 P.2d 481 (1934).

${ }^{5}$ Sheward v. Virtue, 20 Cal.2d 410, 126 P.2d 345 (1942).

${ }^{6}$ Woodworkers Tool Works v. Byrne, 191 F.2d 667 (9th Cir. 1951).

${ }^{7}$ ReVISED UNIForax SAIES Act $\$ 1 \mathrm{~b}$, Comment $b$ at 125 (2d draft 1941).

8 Poore v. Edgar Bros. Co., 33 Cal. App.2d 6, 90 P.2d 808 (1939).

9 Eason v. Kelly Pipe Co., 16 Cal. App.2d 88, 60 P.2d 488 (1936).

10 Phillips v. Ogle Aluminum Furniture Inc., 106 Cal. App.2d 650, 235 P.2d 857 (1951).

11 Marko v. Sears, Roebuck and Co., 24 N.J. Super. 295, 94 A.2d 348 (1953).

12 Poretz v. R. H. Macy \& Co., 119 N.Y.S.2d 211 (1953).

13 Blissenbach, a Minor, v. Yanko, 90 Ohio App. 557, 107 N.E.2d 409 (1951).

14 Yaun v. Allis-Chalmers Mfg. Co., 253 Wis. 558, 34 N.W.2d 853 (1948).

15 Auten v. Livingston, 201 Okla. 467, 207 P.2d 256 (1949).

16 Simmons v. Rhodes \& Jamieson, Ltd., 133 A.C.A. 798, 284 P.2d 813 (1955), rehearing granted; Dalton v. Pioneer Sand \& Gravel Co., 37 Wash.2d 946, 227 P.2d 173 (1951).

17 Wilkinson v. Rich's Inc., 77 Ga. App. 239, 48 S.E.2d 552 (1948). 
onion-topping machine ${ }^{18} \mathrm{~A}$ harvester ${ }^{19} \mathrm{~A}$ harvester of $x$ degrees safety factor will not normally injure the user. But since a certain number of people are known to be "nonmechanical," bad with their hands, butterfingers, perhaps there is a statistical risk of injury to one person per thousand users, quite apart from any contributory negligence considerations. A harvester of $x+1$ degrees of safety factor might reduce the risk of 1 in $100,000 . X+2$ degrees could turn it into a negligible 1 in $10,000,000$, but would also treble the cost and cause the benefit of the harvester to be confined to whatever percentage of the originally potential buyers can afford the higher price. At which point is strict liability imposed? The same probIem exists with allergic plaintiffs. Use of a certain ingredient in a face powder as a $1.5 \%$ constituent would cause irritation in perhaps 1 in 100 persons with hypersensitive skins. Reduction to $0.9 \%$ might lower the risk of harm to allergic users to 1 in 1 million, but perhaps involve the use of a more expensive substitute and destroy the beneficial qualities of the product for persons of normal sensitiveness. This particular aspect of the problem will be developed at greater length subsequently. The charismatic problem still remains, and perhaps the fairest formulation of the criterion is to say that a product is defective if it causes injury during normal, reasonable use. In other words, the enterprise is liable for the typical risks of its operation.

Exploding bottles deserve especial mention. When a person is injured by the explosion of a beer bottle, ${ }^{20}$ it is readily apparent that the explosion could quite conceivably have resulted from the jolting and rattling for which the long journey froin the bottling plant to the scene of the accident must have provided many an occasion. Although the crack, or flaw, or increase in internal pressure may not have occurred, therefore, until some stage in the transportation of the bottle while it was in the control of an intermediate distributor, it is, nevertheless, considered that a bottle so weak that it is susceptible of developing cracks, etc., under normal transportation conditions, is in fact "defective." Despite earlier doubts, ${ }^{21}$ this was established in California in Escola v. Coca Cola Bottling Co., where the supreme court categorically stated:"22 "Sound and properly prepared

18 Campo v. Scofield, 301 N.Y. 468, 95 N.E.2d 802 (1950); see Note, 17 Broordyn L. REv. 349 (1951).

19 Snyder v. Holt Manufacturing Co., 134 Cal. 324, 66 Pac. 311 (1901).

20 What follows is not confined to bottles of food or drink. Saporito v. Purex Corp., 40 Cal.2d 608, 255 P.2d 7 (1953) and DeCorsey v. Purex Corp., 92 Cal. App.2d 669, 207 P.2d 616 (1949), both cases involving cleaning fluid bottles.

21 Gerber v. Faber, 54 Cal. App.2d 674, 129 P.2d 485 (1942).

2224 Cal.2d 453, 459, 150 P.2d 436, 439 (1944). Cf. Torgesen v. Schultz, 192 N.Y. 156, 161, 84 N.E. 956, 958 (1908), where the court said: "The defendant might reasonably be held chargeable with knowledge that it was customary, especially in hot weather, to place siphons charged with aerated water in contact with ice, and in view of this fact a jury might well find that the tests applied to such bottles should be such as to render it tolerably certain that they would not explode when thus used." 
bottles of carbonated liquids do not ordinarily explode when carefully handled." Justice Traynor in a concurring opinion in a later case laid the matter upon its proper foundations when he said: ${ }^{23}$

A bottle can hardly be considered not defective if it cannot safely withstand the treatment it will normally receive in carrying its contents to the consumer.

B.

\section{Defectiveness In Fact}

If the plaintiff establishes that the alleged condition of the product was within this category of "defective," he has still to substantiate the allegation. The physical difficulty of proof of the existence of the defect is sometimes great. In the case of a foreign substance in a food, it is easy. The direct evidence of witnesses is almost invariably available. Where the defect is less tangible and more speculative, direct evidence is ruled out. Except in the rarest cases, however, ${ }^{24}$ circumstantial evidence is available. Particularly is this so in food cases, where, foreign substances apart, it is hard to prove deleteriousness after the corpus delicti has been consumed. The court in Loucks v. Morley ${ }^{25}$ found that illness had been caused by "... sone deleterious condition of said pudding, the nature of which this court is unable to find, from the evidence ...." This probably represents a peak of judicial conservatism in not giving weight to circumstantial evidence. There are many factors which can aid a plaintiff. In the particular instance of adulterated food, they could be grouped as follows.

\section{Source}

Expert medical evidence may show that the illness alleged probably, or almost certainly, had its cause in the consumption of bad food such as that

${ }^{23}$ Gordon v. Aztec Brewing Co., 33 Cal.2d 514, 532, 203 P.2d 522, 533 (1949). In Stolle v. Anheuser-Busch, 307 Mo. 520, 529, 271 S.W. 497, 500 (1925), the court said: "These bottled beverages, containing explosive gases, are put upon the market with the intention that they will be transported throughout the country and sold to consuners for the profit of the manufacturer. Obviously this should be at his risk. Public policy requires that the manufacturer should assume the risks and liazards of explosion incident to the reasonable and ordinarily careful transportation and handling of these goods in the usual course of business." That the circulation of a bottle unable to stand up to normal handling is an act of negligence is the only possible conclusion to be drawn from the many cases loolding a bottler liable for negligence, where the bottle went through the intermediate control of a distributor, on res ispa loquitur principles. Bailey, The Res Ipsa Loquitur Dotrine and the Bottled Beverage, 1949 INs. L.J. 331, scemingly refuses to recognize this.

24 Markulics v. Maico Co., Inc., 74 Cal. App.2d 66, 168 P.2d 35 (1946) (hearing aid device not proved so defective as to cause burns); Swyny v. Caylor, 7 Cal. App.2d 627, 46 P.2d 979 (1935) (fall of wall bed unexplained); Cleary v. Maris Co., 173 Misc. 954, 19 N.Y.S.2d 38 (1940) (failure to prove lead poisoning from use of lead nipple shiclds).

$2539 \mathrm{Cal}$. App. 570, 571, 179 Pac. 529, 530 (1919). The deleteriousness of food was unproved in Blackman v. Lundy, 193 Misc. 745, 87 N.Y.S.2d 181 (1948); Mente v. Albers Super Markets, Inc., 92 Ohio App. 152, 109 N.E.2d 527 (1951). 
allegedly circulated by defendant. Thus, trichinosis points exclusively to pork, $^{28}$ and ptomaine poisoning ${ }^{27}$ or enteritis ${ }^{28}$ are almost as divinatory.

\section{Timing}

Expert medical evidence may show that illness such as that alleged normally takes a certain period to develop, and this may be conbined with plaintiff's evidence that he contracted the illness within that period from the time of consuming the food. ${ }^{29}$

\section{Elimination of Other Causes}

There may be evidence that the plaintiff did not eat other foods which might have been the cause of his illness for some time before eating the defendant's food, ${ }^{30}$ that he ate very little on that day and that what he did eat was an unlikely source, ${ }^{31}$ that another person who normally eats the same food as the plaintiff (such as a spouse) did not eat this particular food and was unharmed, ${ }^{32}$ or that others did eat of this same alleged deleterious food and were also taken ill. ${ }^{33}$

It seems that not all of these types of circumstantial evidence are necessary, nor conclusive, some combination of then being sufficient. Of course it is open to defendant to point up their absence or deficiency in an effort to deny causation in fact. Similar evidence is often pleaded in non-food cases. ${ }^{34}$ The exploding bottle once again presents a separate and complex question. What sort of evidence of "normal" treatment must the plaintiff

${ }^{26}$ Gindraux v. Maurice Mercantile Co., 4 Cal.2d 206, 47 P.2d 708 (1935); Russell v. Stores, 96 N.H. 471,79 A.2d 573 (1951).

27 Stell v. Townsends C. G. Fruits, 138 Cal. App. 777, 28 P.2d 1077 (1934). Contrast Goodwin v. Misticos, 207 Miss. 361, 42 So.2d 397 (1949). For an eloquent presentation of the possibility of food poisoning deriving from staphylococci which may often attach to the food long after leaving the processor's plan, see Condon, The Practical Impact of the Proposed Uniform Commercial Code on Food Poisoning Cases, 5 Food DRUG CoMs. L.J. 213, 222-27 (1950). 28 Jensen v. Berris, 31 Cal. App.2d 537, 88 P.2d 220 (1939).

29 Gindraux v. Maurice Mercantile Co., 4 Cal.2d 206, 47 P.2d 708 (1935); Houchens Food Market of Bowling Green v. Keith, 247 S.W.2d 521 (Ky. App. 1952) ; Murray v. P. Ballantine \& Sons, 75 R.I. 13, 62 A.2d 895'(1948), subsequent opinion, 63 A.2d 730 (R.I. 1949).

30 Gindraux v. Maurice Mercantile Co., 4 Cal.2d 206, 47 P.2d 708 (1935) ; Criswell Baking Co. v. Milligan, 77 Ga. App. 861, 50 S.E.2d 136 (1948).

31 Stell v. Townsends C. G. Fruits, 138 Cal. App. 777, 28 P.2d 1077 (1934).

32 Franke's Inc. v. Wallace, 219 Ark. 46\%, 242 S.W.2d 968 (1951); Stell v. Townsends C. G. Fruits, 138 Cal. App. 777, 28 P.2d 1077 (1934); Kroger Grocery, Etc. Co. v. Dunn, 181 Va. 390, 25 S.E.2d 254 (1943).

33 Jensen v. Berris, 31 Cal. App.2d 537, 88 P.2d 220 (1939); Turner v. Wilson, 86 S.E. $2 d$ 867 (N.C. 1955); Geisness v. Scow Bay Packing Co., 16 Wash.2d 1, 132 P.2d 740 (1942). Cf. the cases holding that evidence of other bottles from defendant's plant exploding more or less contemporaneously strengthens the inference of defectiveness (and of negligence), e.g., Maybach v. Falstaff Brewing Corp., 359 Mo. 446, 222 S.W.2d 87 (1949).

34 Such evidence was sufficient to allow the inference of the unsafe character of shampoo where plaintiff went bald. Pietrus v. J. R. Watkins Co., 229 Minn. 179, 38 N.W.2d 799 (1949). 
offer to show defectiveness? It is usually stated that he must establish, by a preponderance of the evidence,to the satisfaction of a jury, that there has been no unusual or abnormal handling of the bottle between the time of leaving defendant's hands and the time of the accident. It is at this stage that we meet our old friend res ipsa loquitur again. Here, however, instead of inferring from the evidence a negligent act on the part of the defendant, the court is inferring simply the defectiveness of the product, from which in turn a negligent act may be inferred (is such a defect does not normally occur without negligence). That the act of allowing the sack of flour to fall in Byrne v. Boadle ${ }^{35}$ was in fact the defendant's act and in fact caused plaintiff's injury was not in question. The only issue was whether the act was negligent or not. To this question res ipsa loquitur was applied in what may be termed its legal function, which has already been discussed with regard to products liability. ${ }^{36}$ The inferences that the product was defective and was so on leaving defendant's bands are what may be called applications of res ipsa loquitur in its factual function, insofar as the courts use the Latin terminology in this situation.

Where the defendan $t^{37}$ delivers the bottle directly to the plaintiff, the necessary circumstantial proof of defectiveness in the event of explosion consists merely in lack of contributory negligence (in this contingency the burden of proof of contributory negligence is quite properly reversed). Plaintiff must show that he handled and stored the bottle properly. Where there is an intermediate distributor, or many of them, plaintiff must show due care on their part also ${ }^{38}$ Such evidence was lacking in Gerber v. Faber ${ }^{30}$ where it appeared that the bottle might have languished a week on the whholesaler's truck, and that other customers of the retailer were in the

352 H. \& C. 722, 159 Eng. Rep. 299 (Ex. 1863).

36 See Part I, 43 CaIIF. L. REv. at 635-40.

37 The defendant is normally the bottler in these cases. A prima facie case was made out against a retailer, however, in Day v. Grand Union Co., 280 App. Div. 253, 113 N.Y.S.2d 436 (1952), on proof of an explosion of bottled beer in a self-service store. Contra, Monroe v. H. G. Hill Stores, 51 So.2d 645 (La. App. 1951).

38 As to the plaintiff's handling, see Piacun v. Louisiana Coca Cola Bottling Co., 33 So.2d 421, 426 (La.App. 1947), where plaintiff failed because "there is no acceptable proof that plaintiff did not himself improperly handle the bottle or that the breaking of it was not the result of his own carelessness"; Zentz v. Coca Cola Bottling Co., 39 Cal.2d 436, 247 P.2d 344 (1952); Honea v. City Dairy, Inc., 22 Cal.2d 614, 140 P.2d 369 (1943); Starke Coca Cola Bottling Co. v. Carrington, 159 Fla. 718, 32 So.2d 583 (1947) ; Poulos v. Coca Cola Botthing Co. of Boston, 322 Mass. 386, 77 N.E.2d 405 (1948); Lawton Coca Cola Bottling Co. v. Shaughnessy, 202 Okla. 610, 216 P.2d 579 (1949); Gedding v. Marsh, [1920] 1 K.B. 668.

As to evidence of retailer's handling, see Kees v. Canada Dry Ginger Ale, 225 S.W.2d 169 (Mo. App. 1949) ; Fick v. Pilsener Brewing Co., 54 Ohio Abs. 97, 86 N.E.2d 616 (1949) ; Fankins v. Coca Cola Bottling Co., 151 Tex. 303, 249 S.W.2d 1008 (1952).

${ }^{39} 54$ Cal. App.2d 674, 129 P.2d 485 (1942). Accord, Boykin v. Chase Bottling Works, 32 Tenn. App. 508, 222 S.W.2d 889 (1949) (where an ice man had hroken up a 50 pound block of ice with his pick on top of the bottles). 
habit of removing bottles themselves from his cooler..$^{40}$ This application of circumstantial evidence was fully canvassed in the two cases, Gorden $v$. Aztec Brewing Co.41 and $M c$ Clelland v. Acme Brewing Co. ${ }^{42}$ There evidence was introduced to show that no accidents had occurred to the wholesaler's trucks or in its warehouse during the relevant period. There was, however, an important extension of this principle in DeCorsey v. Purex Corparation, where the plaintiff presented no evidence at all of the wholesaler's handling, and the court said that since the product was manufactured and packaged to meet normal handling, ${ }^{43}$

... it would have been unreasonable to require plaintiff to prove the absence of some unusual, unexpected conditions that might have exposed the bottle to excessive heat.

The court deliberately shied away from res ipsa loquitur and rested its decision on other circumstantial evidence, but the result is significant. Its effect is to change the burden of proof. Proper handling was presumed,

10 But quaere whether such a habit, if found to be prevalent, could not be argued as being within the area of reasonable prevision, and the marketer held liable for the risk as a cost of the enterprise?

1133 Cal.2d 514, 203 P.2d 522 (1949).

4292 Cal. App2d 698, 207 P.2d 591 (1949). Accord with these two cases: Coca Cola Bottling Co. of Fort Smith v. Hicks, 215 Ark. 803, 223 S.W.2d 762 (1949); Johnson v. Louisiana Coca Cola Bottling Co., 63 So.2d 459 (La. App. 1953); Ruffin v. Coca Cola Bottling Co., 311 Mass. 514, 42 N.E.2d 259 (1942); Stephens v. Coca Cola Bottling Co., 215 S.W.2d 50 (Mo. App. 1948), subsequent opinion, 232 S.W.2d 181 (Mo. App. 1950). Contra, Curley v. Ruppert, 272 App. Div. 441, 71 N.Y.S.2d 578 (1947), where, in spite of evidence of no tampering, the court refused to infer the defective condition of a bottle of beer (two judges dissenting). There is often criticisin of these cases, and of their originator, Payne v. Rome Coca Cola Bottling Co., 10 Ga.App. 762, 73 S.E. 1087 (1912), on the ground that they "double-apply" res ipsa loquitur. See, e.g., Bailey, The Res Ipsa Loquitur Doctrine and the Bottled Beverage, 1949 Ins. L.J. 331 ; Gerber v. Faber, 54 Cal. App.2d 674, 684, 129 P.2d 485, 491 (1942). "In a case where plaintifi undertakes by his proof to eliminate all of the causes except the negligence of one defendant, he cannot then invoke the doctrine as against that defendant . . . " Ibid. This argument is vitiated by a failure to distinguish the processes involved. Plaintiff inust first prove that the bottle was defective. This he does by proving his own proper handling, which is circumstantial evidence. Next he must show that the bottle was defective when it left defendant's hands, and this he does hy proving proper intermediate handling. This again is circumstantial evidence. Finally he must prove that the bottle emerged from the bottling plant defective as a result of some negligent act of defendant. For this step, and this step alone, he falls back on the res ipsa loquitur rule, by which the jury is permitted to infer that only a negligent act for which defendant is responsible could have resulted in the issuing of the defective product (although, in effect, "most likely" is substituted for "only" since plaintiff does not have to exclude every possibility of non-neghgence; the accident need only be one which "ordinarily" occurs as a result of neghigence). It should be noted that initial legitimacy of an inference of one fact from another is a question for the court, not the jury. James, Proof of the Breach in Negligence Cases (Including Res Ipsa Loquitur), 37 VA. L. REv. 179, 186 (1951). See also Peairs, The God in the Machine, 29 B.U.L. Rev. 37, 42-46, 59-61 (1949).

4392 Cal. App.2d 669, 673, 207 P.2d 616, 618 (1949). Accord, Pattinson v. Coca Cola Bottling Co., 333 Mich. 253, 52 N.W.2d 688 (1952). 
and in order to prove the absence of any defect, the defendant would have had to show improper handling. ${ }^{44}$ There was no hint of this in the Gordon or Escola cases, but it is quite consistent with their approach. It remains to be seen whether it will be supported by the supreme court.

\section{Defectiveness at the Time of Leaving the Enterprise}

The final question concerning causation in fact, leaving to one side the issue of legal responsibility, is the sufficiency of evidence that the defect is traceable to the defendant (as distinct from traceable to the product, which we now assume). It may of course be difficult even to trace the product beyond the retailer. ${ }^{45}$ That may depend upon the way the product is marked or otherwise identified, if at all, and upon the information supplied by the retailer. The restaurant cases are probably on a different footing for this reason: the argument for holding the restaurateur to strict liability is strengthened by the impossibility of determining which of many possible ingredients in a dish was deleterious. ${ }^{46}$ Assuming, however, that it is established that the product did emanate from the defendant, can he avoid liability on the ground that it was not defective at the time he produced it? ${ }^{47}$

Where there is direct delivery, ${ }^{48}$ the plaintiff lias merely to prove that he handled the product properly and that the defect did not appear to

44 This is implicit in the Pattinson case, supra note 43 (where defendant bottler dehivered to plaintiff waitress' employer and she recovered without evidence of the employer's proper handling). The court said: "There is nothing in the record to indicate that any external force whatever was applied to it immediately prior to the breaking." Id. at 259,52 N.W.2d at 691 .

45 See Comarow v. Levy, 115 N.Y.S.2d 873 (1952).

46 See Part I, 43 CACIF. L. REv. at 622-23, and Comment, 10 So. CAuTr. L. Rev. 188 (1937), pointing out that manufacturer's hability is of little value in restaurant cases, and even suggesting that serving food is an ultrahazardous activity. De Luccio v. Wagner Baking Corp., 201 Misc. 984, 115 N.Y.S.2d 728 (1952), is a good example of a patron failing because although negligence is clear it is not certain whose negligence it is. For a good argument against the restaurateur's strict liability, however, see the opinion of Chief Justice Bond in Dining Hall Co. v. Swingler, 173 Md. 490, 504-05, 197 Atl. 105, 116-17 (1938).

47 This was the factor defeating the plaintiff in Crigger v. Coca Cola Bottling Co, 132 Tenn. 545, 179 S.W. 155 (1915). There are cases bolding tbat where the jumping warranty is imposed on the inanufacturer, proof beyond reasonable doubt that the defect could not possibly have occurred while the product was in defendant's hands does not preclude recovery: Coca Cola Bottling Co. v. Burgess, 195 S.W.2d 379 (Tex. Civ. App. 1946). This does not seem in accord with the explicit formulations of warranty liability, but illustrates the development toward the concept of allocating the risk without reference to fault, the manufacturing enterprise bearing the risk of defects occurring in the ordinary course of inarket distribution. Contra, Barker v. Weingarten Riverside Co., 232 S.W.2d 692 (Tex. Civ. App. 1950) ; Williams v. Paducah Coca Cola Bottling Co., 343 MI. App. 1, 11, 98 N.E.2d 164, 168-69 (1951) (where the court said: ". . . the warranty which runs with the article is a warranty that when the product leaves the control of the manufacturer or bottler it was fit for human consumption").

48 Delivery is made out by purchase from a vending machine installed by bottler on other premises. Stein v. Woodlawn Farm Dairy Co., 50 Lack. Jur. 1 (Pa. Com. Pl. 1948). 
him. ${ }^{49}$ Length of time between delivery and discovery of the defect will often defeat the action..$^{50}$ In Reese v. Smith ${ }^{51}$ plaintiff did not satisfy the court that maggots which apparently got inside some sausage that she ate were there at the time of purchase from the defendant.

In the case of the intervention of distributors, a showing of proper care by them once again raises the imference that the defect existed at the time of circulation by defendant. In strict theory, the defendant can escape liability if proper intermediate handling is not shown..$^{52}$ However, there is the possibility that the burden of proof is being changed, as in the proof of defectiveness of an exploding bottle, by cases like DeCorsey v. Purex Corporation. ${ }^{53}$ The listory of this development begins with the sealed container cases. Evidence that glass existed in bread that was sealed in cellophane by defendant, ${ }^{54}$ and that maggots were present in a sandwich wrapped in wax paper and sealed with metal clamps by defendant, ${ }^{55}$ was considered sufficient to support the inference that both foreign substances were present at the time of circulation by defendant marketers. Denying the production of the sealed package could destroy the basis of this inference, but this is a rare argument on the part of manufacturers' counsel. It would take a naive jury to accept it and would presumably be extremely detrimental to public relations. There is legitimate ground here for the

40 Burr v. Sherwin Williams Co., 42 Cal.2d 682, 268 P.2d 1041 (1954); Schmidt v. Union Oil Co., 27 Cal. App. 366, 149 Pac. 1014 (1915).

60 Plaintiff failed in El Zarape Etc. Factory v. Plant Food Corp., 90 Cal. App.2d 336, 203 P.2d 13 (1949), where the first evidence of unfitness was discovered six weeks after delivery of corn. See also Piacun v. Louisiana Coca Cola Bottling Co., 33 So.2d 421 (La. App. 1947).

519 Cal.2d 324, 70 P.2d 933 (1937).

62 Trowbridge v. Abrasive Co. of Philadelphia, 190 F.2d 825 (3d Cir. 1951); Coca Cola Bot. Works v. Sullivan, 178 Teun. 405, 158 S.W.2d 721 (1942); Cunningham v. Coca Cola Co., 137 W.Va. 827, 74 S.E.2d 409 (1953). The fact that this is a separable part of the res ipsa loquitur doctrine, and wider than it, is illustrated well in Tennebaum v. Pendergast, 55 Ohio L. Abs. 231, 89 N.E.2d 490 (1948), where res ipsa loquitur was refused and a breach of warranty action disallowed for lack of proximate cause for precisely the sane reason: lack of evidence of proper intermediate handling. Accord, Maryland Cas. Co. v. Independent Metal Products Co., 99 F.Supp. 862 (D. Neb. 1951), aff'd, 203 F.2d 838 (8th Cir. 1953). The distinction and the analysis here adopted are employed by the court in Maybach v. Falstaff Brewing Corp., 359 Mo. 446, 453-55, 222 S.W.2d 87, 90-91 (1949).

E3 92 Cal. App.2d 669, 207 P.2d 616 (1949).

54 Dryden v. Continental Baking, 11 Cal.2d 33, 77 P.2d 833 (1938). Accord, Smith v. Great Atlantic \& Pacific Tea Co., 170 F.2d 474 (8th Cir. 1948) (canned spinach); Liggett \& Myers Tobacco Co., v. DeLape, 109 F.2d 598 (9th Cir. 1940) (cigarette in pack). Cf. Quaker Oats Co. v. Davis, 33 Tenn. App. 373, 232 S.W.2d 282 (1949), where accessibility to the public of feedbags in retailer's storeroom did not defeat an inference that manufacturer mislabeled thein.

55 Klein v. Duchess Sandwich Co., Ltd., 14 Cal.2d 272, 93 P.2d 799 (1939). Contra dictum in Jordan v. Coca Cola Co. of Utah, 117 Utah 578-86, 218 P.2d 660, 664 (1950), that a folded over and stapled cellophane bag can be opened and resealed in a manner identical with the original packing. 
distinction between packaged and unsealed goods, although the point cannot be pressed too far. The court in a landmark case from Tennessee ${ }^{5 b}$ found two situations in which res ipsa loquitur (in its "factual" function) could apply where there was no direct delivery to plaintiff. One was where the product comes so sealed as to exclude the possibility of tampering, as in a can. The other is where there is a foreign substance so embedded in the product as to demonstrate conclusively its insertion at the time of manufacture, such as the pebble in the bread roll in Cushing $v$. Rodman. ${ }^{67}$ This is a fair analysis. It is not the separate sealing that works the magic, but the practical possibility in the particular case of intermediate tampering.

Now it is quite within the bounds of possibility that someone either deliberately, carelessly or innocently opened the container or package, introduced the foreign substance, and then resealed it. The concept of the "malevolent person" appeared as early as 1915, in Crigger v. Coca Cola Bottling $\mathrm{Co}^{58}$ There is hardly a practicable commercial method of packaging or sealing that could guarantee against this possibility. The court in the cases cited above, however, presumably considered that it was so unlikely that it could be discounted, althouglu one supposes that if defendant could prove such an incident, the plaintiff would be nonsuited. The conjecture of the "malevolent person" was dismissed as "utterly unrealistic and fantastic" in a subsequent Tennessee case. ${ }^{69}$ In other words, the risk of unusual interference is squarely placed upon the marketer. Here is a good illustration of Judge Jerome Frank's thesis that policy decisions are often disguised behind fact decisions. ${ }^{60}$ Motivations of policy concerning the division of marketing risks between marketer and consumer have in. fluenced the courts in deciding what is techmically a pure fact, viz., whether a defect existed on leaving defendant's hands. In the case of sealed containers or embedded foreign substances, the marketer is not protected against the risk of unusual tampering unless he can prove the specific incident. ${ }^{61}$

56 Coca Cola Bot. Works v. Sullivan, 178 Tenn. 405, 158 S.W.2d 721 (1942). See Annot., 171 A.L.R. 1209 (1947), for authorities, and also extensive citations in Dickerson, Producrs LIABIIITY AND THE Food Consuager 115 n.5, 120 n.1 (1951).

5782 F.2d 864 (D.C. Cir. 1936). Contra, Piazza v. Fischer Baking Co., 197 Misc. 418, 98 N.Y.S.2d 508 (1950), aff d, 200 Misc. 834, 111 N.Y.S.2d 245 (1951) (screw embedded in bread).

58132 Tenn. 545, 179 S.W. 155 (1915). See Comment, Res Ipsa Loguitur in Tennessee, 22 TENN. L. Rev. 925, 939 (1953).

59 Boykin v. Chase Bottling Works, 32 Tenn. App. 508, 222 S.W.2d 889 (1949).

60 Frank, LAW AND TaE MOdERN MIND (2d ed. 1949).

81 If this neat point ever arose in a California court it would present a fine example of the basic conflict of policies. The need for compensation is as urgent where an unknown or inaccessible stranger has introduced the foreign substance as where the marketer did, and the case for distributing the loss over the consuming public is equally strong. The defendant, however, can appeal most compellingly to the retributive instinets of a jury or judge and truthfully disclaim any moral responsibility for the accident. The dilemma is in fact irresoluble short of the drastic revision of our conception of the judicial function in this field along the lines of workmens' compensation (as will be suggested later). 
The question is: How far does this extend? There are indications that it is not accepted in the "mouse in the Coca Cola" cases. Although the plaintiff succeeded in Medeiros v. Coca Cola Bottling Co. ${ }^{62}$ and in Moss v. Coca Cola Bottling Co., ${ }^{63}$ and nominally it was found that the foreign substances were present at the time of leaving the bottling plant, the court in both cases stressed the evidence tending to show no intermediate tampering. If this implies that without such evidence plaintiff would fail (and there is plenty of out-of-state authority for this ${ }^{64}$ ), then the Klein and Dryden cases are deprived of much of their scope. The sealed nature of the bottle should allow the inference of no tampering just as much as the sealed nature of a wax-wrapped sandwich. Is it any more likely that a third party will introduce a mouse into a theretofore unopened Coca Cola bottle than that a stranger will place maggots in a sealed sandwich? And if, as suggested, the Klein case illustrates a policy of making the marketer compensate for all the typical risks of marketing his product, how can such a

6257 Cal. App.2d 707, 135 P.2d 676 (1943).

63103 Cal. App.2d 380, 229 P.2d 802 (1951).

64 Fisher v. Washington Coca Cola Bottling Works, 84 F.2d 261 (D.C. Cir. 1936) (barley); Todd v. Coca Cola Bottling Co. of Puerto Rico, 88 F. Supp. 870 (D. Puerto Rico 1950) (cockroach); Williams v. Paducah Cola Cola Bottling Co., 343 Ill. App. 1, 98 N.E.2d 164 (1951) (matchbox); East Kentucky Beverage Co. v. Stumbo, 313 Ky. 66, 68, 230 S.W.2d 106, 107 (1950) (contraceptive) ("there was ample opportunity for the bottle to have been tampered with or for a bottle to have been removed from a case of Pepsi Cola and one with a rubber in it placed in its stead"); Mayerhefer v. Louisiana Coca Cola Bottling Co., 219 La. 319, 52 So.2d 866 (1951) (iodine); Day v. Hammond Coca Cola Bottling Co., 53 So.2d 447 (La. App. 1951) (mouse); Nichols v. Louisiana Coca Cola Bottling Co., 46 So.2d 695 (La. App. 1950) (roach); Coca Cola Bot. Works v. Sullivan, 178 Tenn. 405, 158 S.W.2d 721 (1942) (glass); Bottling Co. v. Rowland, 16 Tenn. App. 184, 66 S.W.2d 272 (1932) (mouse) ; Amarillo Coca Cola Bottling Co. v. Loudder, 207 S.W.2d 632 (Tex. Civ. App. 1947) (mouse); Jordan v. Coca Cola Co. of Utah, 117 Utah 578, 218 P.2d 660 (1950) (fiy) (two judges dissenting on the ground that possibility of malevolent interference was properly a question for jury).

In most of these cases there were factors strengthening the possibility of interference or substitution. In the Jordan case, for example, the bottler's driver used to exchange iced for warm bottles with workmen before delivery to the retailer (quaere: Would the bottler still be liable on respondeat superior?) and many persons had access to the vending machine from which plaintiff bought. The court also judicially noticed the prevalence of "horse-play" in factories where men were thrown together in numbers. In LeBlanc v. Louisiana Coca Cola Bottling Co., 221 La. 919, 932, 60 So.2d 873, 877 (1952), Hawthorne, J., (dissenting) noted the frequency of the practice of New Orleans bartenders filling up discarded beer bottles with residue left by patrons, and recapping then and selling them as new. (See also LeBlanc, J.'s, concurring opinion, id. at 930,60 So.2d at 876-77). As was reenarked with some truth by the court in Beaunont Coca Cola Bottling Co. v. Guillot, 222 S.W.2d 141, 144 (Tex. Civ. App. 1949), it would be extremely difficult for someone to imsert a foreign substance in a coke bottle without some recapping machine which would retain the pressure of the gases in the bottle. "Horse-play" is more likely to take the form of inserting something after the final delivery, in between plaintiff opening the bottle and consuming it, while his back is turned, and its possibility must be guarded against in requiring strong proof of the impossibility of anything being inserted between final purchase and consumption, not in the intermediate distribution period. 
policy distinguish the bottle cases? In both cases the marketer induces reliance upon the hygienic nature of his product by the sealing, and in both cases the argument for placing upon his shoulder the risk of intermediate tampering is equally strong. There is a strong body of authority for this view, and it is hoped that Cahfornia will follow it. ${ }^{05}$

Once again, the exploding bottle may present a different case. The showing of evidence of no tampering is necessary in any event, to prove the defective condition of the bottle, as has been seen. Perhaps there is less basis in common experience for allowing an inference of no tampering here than in foreign substance cases. As was said in a Delaware case, "It is common knowledge that bottled beverages are transported and handled with abandon." ${ }^{16}$ However, the cases are fairly unanimous in requiring the

65 Polvere v. Chunky Chocolate Corp., 140 N.Y.S.2d 322 (1955) ; LeBlanc v. Louisiana Coca Cola Bottling Co., 221 La. 919, 924, 60 So.2d 873, 874 (1952) ("When it is shown that there was nothing unusual about the bottle and that it was in apparent good condition at the time the plaintiff uncapped it, it is logical to infer that it had not been mishandled or its contents disturbed after it left the manufacturer's plan for distribution.") ; Alston v. J. L. Prescott Co., 10 N. J. Super. 116, 125-26, 76 A.2d 686, 691 (1950) ["The notion that a manufacturer and bottler.... in the absence of any other explanatory probability can annihilate the probative or inferential function of the rule of res ipsa loquitur by merely disclosing that the article has since its preparation for sale been successively in the possession of a commission merchant or wholesale distributor and retailer before reaching the plaintiff, seems in view of the activities and experiences of the modern age somewhat absurd. This is particularly so in the absence of any evidence, circumstantial or otherwise, that the container in the course of its itinerary zoas subjected to any misuse." (Emphasis added.)] (i.e., the burden of proof is changed and it is for the defendant to show that there was intermediate mishandling); Magic City Bottling Co. v. Tolbert, 34 Ala. App. 516, 41 So.2d 619 (1949); Birmingham Coca Cola Bottling Co. v. Sellers, 34 Ala. App. 355, 39 So.2d 706 (1949) (no evidence of retailer's handling); Patargias v. Coca Cola Bottling Co., 332 Ill. App. 117, 74 N.E.2d 162 (1947) ; Lajoie v. Bilodeau, 148 Me. 359, 93 A.2d 719 (1953) (brush); Cloverland Farms Dairy v. Ellin, 195 Md. 663, 75 A.2d 116 (1950) (kerosene); Carter v. Yardley \& Co., Ltd., 319 Mass. 92, 64 N.E.2d 693, 164 A.L.R. 559 (1946) (no evidence of middlemen's care); Foley v. Coca Cola Bottling Co. of St. Louis, 215 S.W.2d 314 (Mo. App. 1948) (tack) (evidence of no tampering after uncapping by bartender enough) ; Norman v. Jefferson City Coca Cola Bottling Co., 211 S.W.2d 552 (Mo. App. 1948) (mouse) (evidence that bottle was capped at each delivery enough); Oklahoma Coca Cola Bottling Co. v. Dillard, 208 Okla. 126, 128, 253 P.2d 847, 850 (1953) (roach) ("It is possible, but highly improbable, that the bottle had been opened and the roach permitted to enter it after it was delivered to the retailer."); Oklahoma Coca Cola Bottling Co. v. Newton, 205 Okla, 360, 363, 237 P.2d 627, 630 (1951) (fly) ("There is no evidence in the record which even suggests that the fly may have appeared in the bottle as a result of a practical joke, or that it was placed there by some competitive salesman."); Dillon v. William S. Scull Co., 164 Pa. Super. 365, 64 A.2d 525 (1949); Beaumont Coca Cola Bottling Co. v. Guillot, 222 S.W.2d 141 (Tex. Civ. App. 1949); Pepsi Cola Bottling Co. v. McCullers, 189 Va. 89, 52 S.E.2d 257 (1949) (similar facts and holding); Norfolk Coca Cola Bot. Wks. v. Land, 189 Va. 35, 52 S.E.2d 85 (1949) (evidence that bottle was capped at each delivery was sufficient).

${ }^{66}$ Slack v. Premier-Pabst Corp., 40 Del. 97, 104, 5 A.2d 516, 519 (1939). The sort of intermediate mcident in mind here is dropping or knocking the bottle against a hard substance causing it to crack. If there is normal bandling without such an incident, the possible causes of explosion are: (a) excessive internal pressure; (b) defect in the glass caused during filling; (c) visible defect in the glass before filling; (d) latent defect in the glass before filling. Expert evidence was offered to this effect in the Zentz and Escola cases, but judicial notice of this fact 
circumstantial evidence of no tampering in this situation. ${ }^{67}$ From the policy point of view, however, it is not self-evident that a marketer of a bottle which explodes should be held to bear less risks of subsequent defectiveness than a marketer of a bottle which turns out to contain a foreign substance. It could well be argued that the likelihood of the explosion being due to subsequent mishandling (as agamst original defects in the bottle or overcharging) is not so substantially greater than the likelihood of a mouse being inserted in the bottle after sealing (as against introduction during the filling process) as to justify a distinction between them.

Although there is nothing in the Supreme Court of California decisions suggesting a change $m$ the burden of proof along the lines of the Klein case, this is the effect of DeCorsey v. Purex Corporation ${ }^{88}$ which supports the

could probably now be taken. In any event, all these defects are ex hypothesi present at the time of leaving the bottler and all subsequent distributors. In the case of (c) and (d) they are also present at the time of leaving the bottle manufacturer himself. The hazard of relying upon proof of one of these specific defects deters plaintiffs from relying on a suit against the bottle manufacturer, however. Such a suit failed in DeCorsey v. Purex Corporation, 92 Cal. App.2d 669, 207 P.2d 616 (1949), and in Sanders v. Glenshaw Glass Co., 204 F.2d 436 (3d Cir. 1953), cert. denied, 346 U.S. 916 (1953). Smith v. Peerless Glass Co., 259 N.Y. 292, 181 N.E. 576 (1932), is a rare case of a successful action against the glass manufacturer. Res ipsa loquitur in its "legal" function applies to glass bottles, provided that negligence in case (d) is made inferable by evidence of practicable detection techmiques. Escola v. Coca Cola Bottling Co., 24 Cal.2d 453, 150 P.2d 436 (1944). "[T] he law does not require that the injured person eliminate each and every remote possibility of injury to the bottle up to the time of the explosion. It is enough if the evidence is such as to permit a reasonable inference in the hight of all the circumstances that the bottle was not accessible to extraneous harmful influences after it left the possession of the bottler and that it was handled in a reasonably careful manner by the injured person and others who may have had reason to move or touch it," Groves v. Florida Coca Cola Bottling Co., 40 So.2d 128, 130 (Fla. 1949). Stewart v. Crystal Coca Cola Bottling Co., 50 Ariz. 60, 68 P.2d 952 (1937), holding that the explosion could have been due to a sudden change in temperature, seems to be unusual. See Bailey, The Res Ipsa Loquitur Doctrine and the Bottled Beverage, 1949 INs. L.J. 331, 332-33; Note, 1951 WASH. U.L.Q. 216; Annot., 4 A.L.R.2d 466 (1949).

67 Plaintiff failed for lack of affirmative proof of proper handling in: Hughs v. Miami Coca Cola Bottling Co., 155 Fla. 299, 19 So.2d 862 (1944); Roper v. Dad's Root Beer Co., 336 Ill. App. 91, 82 N.E.2d 815 (1948); Kees v. Canada Dry Ginger Ale, 225 S.W.2d 169 (Mo. App. 1949); Smith v. Company, 97 N.H. 522, 92 A.2d 658 (1952); Dunn v. Hoffman Beverage Co., 126 N.J.L. 556, 20 A.2d 352 (1941); Tennebaum v. Pendergast, 55 Ohio L. Abs. 231, 89 N.E.2d 490 (1948); Canada Dry Ginger Ale, Inc. v. Fisher, 201 Okla. 81, 201 P.2d 245 (1948); Soter v. Griesedieck Western Brewery Co., 200 Okla. 302, 193 P.2d $\$ 75$ (1948) ; Boykin v. Chase Bottling Works, 32 Tenn. App. 508, 222 S.W.2d 889 (1949); Hankins v. Coca Cola Bottling Co., 151 Tex. 303, 249 S.W.2d 1008 (1952).

Plaintiff prevailed with varying degrees of proof of proper handling in: Coca Cola Bottling Co. of Fort Smith v. Hicks, 215 Ark. 803, 223 S.W.2d 762 (1949); Groves v. Florida Coca Cola Bottling Co., 40 So.2d 128 (Fla. 1949); Johnson v. Louisiana Coca Cola Bottling Co., 63 So.2d 459 (La. App. 1953); Poulos v. Coca Cola Bottling Co. of Boston, 322 Mass. 386, 77 N.E.2d 405 (1947); Stephens v. Coca Cola Bottling Co. of St. Louis, 215 S.W.2d 50 (Mo. App. 1948), 232 S.W.2d 181 (Mo. App. 1950); Fick v. Pilsener Brewing Co., 54 Ohio L. Abs. 97, 86 N.E.2d 616 (1949); Joly v. Coca Cola Co., 115 Vt. 174, 55 A.2d 181 (1947).

6892 Cal. App.2d 669, 207 P.2d 616 (1949). 
three sealed container cases in holding for the plaintiff despite failure to produce evidence of lack of intermediate tampering. ${ }^{69}$ It is submitted that an extension of the "legal" function of res ipsa loquitur along the lines of Ybarra v. Spangard ${ }^{70}$ could be argued, by which the plaintiff could show proper care as far back as the retailer, jointly sue all the marketers, and then leave it to them to exonerate themselves if they can. It could be spelled from the Ybarra case that successive, not merely concurrent, control over the injuring instrumentality is enough to apply res ipsa loquitur against two defendants. ${ }^{71}$ The precise point was raised in Louisiana, ${ }^{72}$ where the doctrine is applied against colliding motorists on behalf of a third party victim, ${ }^{73}$ but did not have to be decided. In the recent Kansas case of Nichols $v$. Nold, ${ }^{74}$ however, the Ybarra approach was expressly approved in a suit against a manufacturer, distributor and retailer of a carbonated beverage.

It should be pointed out that it is by no means necessary that the same rules of proof apply both to the existence and to the time of appearance of the defect. It might be desirable policy to give to the plaintiff more of

69 This would still allow the manufacturer to require a strong showing of no improper handling by persons outside the normal channels of trade subsequent to delivery by the retailer. See, e.g., Henning v. Thompson, 45 So.2d 755 (Fla. 1950) (where children at a party had been frohicking and getting their own bottles from a tub, plaintiff failed).

$7025 \mathrm{Cal} .2 \mathrm{~d} 486,154$ P.2d 687 (1944). Plaintiff suffered injury to bis shoulder during the time that he was under anaesthetic for an appendectomy operation. He was held to have a cause of action in neghigence against all the surgeons and nurses present at the operation. The court said, id. at 494, 154 P.2d at 691 : "[W] here a plaintiff receives unusual injuries while unconscious and in the course of medical treatment, all those defendants who had any control ever his body or the instrumentalities which might have caused the injuries may properly be called upon to meet the inference of negligence by giving an explanation of their conduct." The case is a fine example of the shift from fault-prinacy to coinpensation-primacy. See James, Proof of the Breach in Negligence Cases (Including Res Ipsa Loquitur), 37 VA. L. REv. 179, 208 (1951), and Comment, 63 HaRv. L. REv. 643, $648 \mathrm{n.15}$ (1950), where it is suggested that at the root of the decision was a desire "to lay the loss upon a company which carried insurance or to encourage the carrying of insurance in the future." There was unusual inaccessibility to the facts on the plaintiff's part, and also an unusual fiduciary relationship between the parties in the case, but it is at least possible that the instrumentality was in the successive control of each defendant.

71 There is already authority for plaintiff's recovery from two negligent defendants in spite of absence of proof of causation by either one. Summers v. Tice, 33 Cal.2d 80, 199 P.2d 1 (1948) (where two defendants not in concert neghigently fired their guns while hunting and one of their bullets mjured plaintifi). See Enrenzweig, Negligence Without Fault 32 (1951), and Notes, 37 Geo. L.J. 627 (1949), 47 Mick. L. REv. 1232 (1949).

72 Monroe v. H. G. Hill Stores, 51 So.2d 645 (La. App. 1951).

73 Weddle v. Phelan, 177 So. 407 (La. App. 1937). See Prosser, Torts 206-08 (2d ed. 1955) ; Prosser, Res Ipsa Loquitur: Collisions of Carriers with Other Vehicles, 30 Irc. L. Rev. 980 (1936).

74174 Kan. 613, 258 P.2d 317 (1953). See also Loch v. Confair, 372 Pa. 212, 93 A.2d 451 (1953) and Maybach v. Falstaff Brewing Corp., 359 Mo. 446, 222 S.W.2d 87 (1949). See generally, EHrenzweig, Negligence Without Fauti 81-82 (1951). 
the benefit of the doubt as to the origin of the defect where he clearly proves that there was a defect. In all the exploding bottle cases, the manner of proving the two facts is identical; the victim can only prove the existence of the defect negatively, by relying upon the presumption that good bottles do not crack under normal handling, and then indicating proper handling all round. In this very process he either succeeds or fails, as the case may be, in laying the defect in time at the defendant's door, as a sort of by-product. But in cases other than exploding bottles, clearer proof might well be required of the existence than of the time of appearance of the defect, ${ }^{75}$ especially from the point of view of eliminating fraud, which generally manifests itself in concocting the defect rather than liaving it introduced before reacling plaintiff. One injured by a mouse in a beer bottle can prove the existence of the defect by direct evidence without the need of presumptions, and it does not follow that lie must embark upon the task of slowing proper intermediate care to lay the defect at defendant's door. The two functions of the "factual" res ipsa loquitur or circumstantial evidence rule are clearly separate and the peculiar difficulties of proving the existance of a defect in the exploding bottle cases (which almost monopolize res ipsa loquitur in this field) slould not be allowed to prevent the development of different rules of proof in altogether different situations. In otlier words, while the plaintiff's burden of slowing circumstantial evidence to prove that the product was defective may operate as a protection of the marketer in cases where the defect is not obvious, the marketer may find that he is denied the same extensive protection where the defective condition of his product is bona fide and proved and lie alleges by way of defense that it became so after leaving his plant. This approach toward responsibility for all subsequent defects incidental to normal distribution, already linted at in the Escola case and especially in Justice Traynor's concurring opinion in the Gordon case, is not at all inconsistent with the res ipsa loquitur precedents.

There is, lowever, another source of protection of the marketer which is linted at. We have seen that he is to some extent protected against an assumption that his product was defective at the time of the accident, but not against an assumption that the defect, once proved, originated while the product was in his hands. Where the exact route which the product has taken is unknown, this is obviously unsatisfactory. In Liggett \& Myers Tobacco Co. v. De Lape ${ }^{76}$ however, the court emphasized not only that the pack had been unopened before the deleterious cigarette was taken out, but also that the pack liad been purchased in the ordinary cliannels of

75 Gray v. Morgan \& Lindsey, Inc., 55 So.2d 273 (La. App. 1951), is a good example of plaintiff's failing to prove the existence of a defect.

${ }^{78} 109$ F.2d 598 (9th Cir. 1940). 
trade. In Baker v. B. F. Goodrich Co. the court noted that the tire which was alleged to be defective had been transported from defendant manufacturer to plaintiff's employer by an agency of the defendant's own choosing, and said: "[T]here is nothing to suggest that any damage was occasioned thereto while in the course of transportation." 77 These cases suggest a possible reformulation of the evidence rule. Here the plaintiff proves not that there had been no unusual accidents or tampering by intermediate distributors, but that the product had been handled by persons whose business it was to distribute it and whose handling was within the contemplation of the manufacturer. It is significant, for example, that testimony by the retailer that substitution of the bottle was impossible because it was always under the surveillance of his employees, as in Underhill $v$. Anciaux, ${ }^{78}$ is acceptable evidence of proper handling. In other words, the plaintiff is given the benefit of the doubt with regard to possible tampering by imdividuals employed in the usual channels of trade, but not by strangers. The rationale presumably is: (1) that such people are less likely to have tampered with the product; (2) that defendant has more chance of investigating the subsequent career of the product to discover any irregularities which would exempt hin from liability; and (3) that defendant is in a better position to insure against liability for injury from defects arising in the ordinary course of distribution. This approach bears out Justice Traynor's declaration in the Gordon case that a bottler is in fact being held liable for defects that develop in the ordinary course of marketing procedures. It would be enough to show not that all distributors in fact observed due care, but that the distribution was undertaken by recognized distributors in the normal course of business.

It is where the product has passed through the hands of a private individual with full title or free possession that the marketer needs protection, and this requirement would give him that. This factor is also back of the reluctance of the courts to allow recovery in the case of secondhand products, except where negligence is established. ${ }^{70}$ In practice, such evidence is what inost of the offered testimony of proper intermediate handling must amount to, and if that is the case it ought to be recognized as such.

Once it is accepted that a marketer is responsible for injury from his product where a defect is shown but not its source, if either (1) the pro-

77 Cal. App.2d 221, 227, 252 P.2d 24, 27 (1953).

7868 Nev. 69, 226 P.2d 794 (1951). Graham v. Cloar, 30 Tenn. App. 306, 205 S.W.2d 764 (1947), seems to support the proposition that proof of passage through normal channels of trade is enough. Diesbourg v. Hazel-Atlas Glass Co., 176 F.2d 410 (3d Cir. 1949), goes much further; a bottle manufacturer was held liable for the explosion after the bottle had been filled with cleaning fluid by a bottler and found its way to a filling station. This would seem to give the manufacturer no protection at all, although it is compensation-primacy carried to its logical result.

79 Lamb v. Otto, 51 Cal. App. 433, 197 Pac. 147 (1921). 
duct was sealed by him, or (2) the product went through the ordinary channels of trade, the way lies open for argument that the second factor is the controlling one, irrespective of whether the product was sealed. Acceptance of such an argument will mark the recognition of the whole question of amount of proof as a matter of policy and not of pure evidence. It will mean that the marketer will be secure in the knowledge that he will be liable for injury caused only by a defect which occurs in his product during its circulation in the ordinary channels of trade. The risk of loss from the acts of subsequent distributors he can guard against by choice of distributor, by mutual arrangement, or by insurance. The necessity of insurance for the subsequent distributors will largely disappear and duplication of insurance premiums will be avoided. The manufacturer's protection in this context would lie in his privilege of demanding genuinely substantial proof that the product really was defective, either by direct evidence, or by fairly burdensome circumstantial evidence. Probably the latter will remain the unique concern of the "exploding bottle" cases.

\section{Reasonable Handling by Intermediate Third Parties}

When there is an intervening act of a third party contributing to the injury, the basic conflict in policies comes into the foreground. The marketer may morally clain exemption, for the notion of visiting one's sins upon another is an anathema to the common law. On the other hand, a victim of the accident who has used the product reasonably and had no control over the intervening party is in no less need of compensation than where there was no such third party intervention. The dilemma of the courts is plain. In fact it appears that in all the cases where recovery in California was denied on this ground, the third party was not only suable (in the sense that there was a good cause of action against him), but engaging in an enterprise which should more appropriately have borne the risk of the injury. ${ }^{80}$ Such third parties have been employers, schoolteachers, ${ }^{81}$ automobile operators ${ }^{82}$ and retailers.

The commonest case is the employer. In Stultz v. Benson Lumber Co., ${ }^{83}$ the plaintiff's employer built a scaffold from a plank manufactured and sold to him by defendant. The employer knew the plank was defective, and

80 Hilson v. Pacific G. \& E. Co., 131 Cal. App. 427, 21 P.2d 662 (1933). But see Simmons v. Rhodes \& Jamiesen, Ltd., 133 A.C.A. 798, 284 P.2d 813 (1955), rehearing granted.

81 Solomon v. Red River Lumber Co., 56 Cal. App. 742, 206 Pac. 498 (1922). If the third party is a stranger, the criterion is the same. Cunningham v. Coca Cola Bottling Co., 87 Cal. App.2d 106, 198 P.2d 333 (1948).

82 Waterman v. Liederman, 16 Cal. App.2d 483, 60 P.2d 881 (1936). Cf. Rae v. California Equipment Co., 12 Cal.2d 563, 86 P.2d 352 (1939) (hoist machine operator negligent). Contra, Benton v. Sloss, 38 Cal.2d 399, 240 P.2d 575 (1952) (automobile operator's recklessness not an intervening agency as the defect was foreseeable by defendant).

836 Cal.2d 688, 59 P.2d 100 (1936) (plank crossgrained and knotty). 
its failure caused plaintiff's injury. The court held that the employer's negligence was an "efficient intervening cause" which broke the chain of causation, and held defendant not liable. ${ }^{84}$ The victim of the accident had a common law action against the employer. In other cases, workmen's compensation was available, if not already received..$^{85}$ That the employing enterprise rather than the marketing enterprise should bear the risk seems obvious where, as in the Stultz case, it was the former which put the product to the specific use in the course of which it failed. The marketer did not know that the employer was going to construct this particular type of scaffold. Similarly, in Lent $v$. Thackaberry ${ }^{86}$ he did not know that the electrical apparatus supplied was to be connected by the employer to a high-voltage cable. In Rae v. California Equipment $\mathrm{Co}^{87}$ an employee was held to have a good cause of action against the furnisher of an electric hoist machine, but the court indicated that it would have been otherwise had the employer known that the hoist was unequipped with safety devices and was uninspected, in violation of an ordinance. These cases might superficially suggest that a concept of fault is allowed to determine which of two enterprises shall bear the risk when both are eligible: the marketer takes the risk unless the employer was morally at fault. In fact, however, it would seem that the question is not so much one of fault as typicality of risk. The liability of the marketer depends on whether the injury was a typical risk of the products enterprise. Risks not typical should be allocated between the employing enterprise and the individual employee. ${ }^{88}$ To some extent this position is achieved by the rule that the employer's negligence, if within the reasonable anticipation of the marketer, will not supersede the latter's responsibility. The Rae case dictum presents a gap in this reasoning. Even if the employer knew of the lack of safety equipment, the risk of injury was still one which should more appropriately attach to the marketing enterprise. At least such an argument could be made, and such considerations of the policy basis of allocating risks between the products and employing enterprises should receive some notice and discussion before the law is ultimately settled.

The retailer cases are curiously muddled. In both California decisions

84 Accord, Pouncy v. Temple, 41 So.2d 139 (La. App. 1949); Roberts v. Southern Pac. Co., 54 Cal. App. 315, 201 Pac. 958 (1921) (railroad not liable for defective car when it informed connecting carrier, plaintiff's employer, of defect).

85 Eason v. Kelly Pipe Co., 16 Cal. App.2d 88, 60 P.2d 488 (1936) ; Lent v. Thackaberry, 136 Cal. App. 783, 32 P.2d 155 (1934); Allen v. Talbot, 6 P.C.L.J. 980 (Super. Ct. San Francisco 1881).

86136 Cal. App. 783, 32 P.2d 155 (1934):

87 12 Cal.2d 563, 86 P.2d 352 (1939).

88 Cf. Gas Co. v. Montgomery Ward \& Co., 231 N.C. 270 , 56 S.E.2d 689 (1949), where a retailer of a gas heater was absolved for negligent misstatement wbere an explosion was attributable to the "palpable" negligence of its installer. 
the retailer was obviously negligent, and the appellate court said so in so many words, yet the concurrent suits against them failed and were not appealed by the plaintiffs. Intermediate discovery by one in the position of retailer, and wanton continued circulation on his part after inadequate testing, must clothe the risk of subsequent injury with the character of atypicality from the manufacturer's viewpoint; ${ }^{89}$ so must failure of a retailer-coiffeur to obey the manufacturer's instructions by allowing a hairwave preparation to touch plaintiff's face and arms. ${ }^{90}$ Unusual circumstances not revealed in the appellate reports must have been back of the failure of the suits against the retailer. Gall v. Union Ice Company, ${ }^{91}$ though not quite in this category, presents interesting support for this reading of the cases. In the "exploding bottle" cases, unreasonable handling by distributors may, as has been seen, excuse the bottler. However, the possibility of holding the bottler liable even for unreasonable handling by a distributor in the normal channels of trade illustrates the fact that back of the law in this situation is the secondary policy question of focussing those risks primarily allocated to the products enterprise, of allocating risks between the various links in the marketing chain, a question which will receive more extended discussion elsewhere.

\section{Reasonable Use by Consumer-Plaintiff}

There are situations where the marketer can legitimately claim that the plaintiff had assumed the risk of the particular injury that occurred and, consequently, that it should not be borne by the enterprise. This is a very broad category, and could include much of the law concerning the necessity of the seller's knowledge of the buyer's purpose and the buyer's reliance upon the seller's skill in the sales implied warranty. ${ }^{92}$ It is also the

89 Catlin v. Union Oil Co., 31 Cal. App. 597, 161 Pac. 29 (1916), where the retailer discovered that the manufacturer had delivered gasoline and coal oil mixed, instead of pure coal oil, assumed from smell and evaporation that two cans were free of gasoline and sold one to plaintiff who was killed lighting his lamp. But "the failure of the [immediate] vendee to properly inspect and test is within the foreseeable risk of the manufacturer." Willey v. Fyrogas Co., 363 Mo. 406, 421, 251 S.W.2d 635, 641 (1952). See Pierce v. Ford Motor Co., 190 F.2d 910 (4th Cir. 1951), cert. denied, 342 U.S. 887 (1951) ; Foley v. The Pittsburgh-Des Moines Co., 363 Pa. 1, 68 A.2d 517 (1949). See Restatenenent, Torts $\$ 396$ (1934); Prosser, TORTs 512 (2d ed. 1955). The manufacturer's proof that injuries were caused solely by the retailer's negligence is a defense in an action against him. Birdsong v. General Motors Corp., 99 F. Supp. 163 (E.D. Pa. 1951). Cf. Boykin v. Chase Bottling Works, 32 Tenn. App. 508, 222 S.W.2d 889 (1949) (where an ice man broke up ice on top of Coca Cola bottles with his pick and one of them subsequently exploded); Ford Motor Co. v. Wagoner, 183 Tenn. 392, 192 S.W.2d 840 (1946). Where, however, the product is dangerous, a third party's negligence was beld no defense in Ky. Independent Oil Co. v. Schnitzler, Admr., 208 Ky. 507, 271 S.W. 570 (1925) (dangerous mixture of gasoline and kerosene-in sharp contrast to the Catlin case in California).

${ }^{30}$ Briggs v. National Industries, Inc., 92 Cal. App.2d 542, 207 P.2d 110 (1949) (derniatitis case).

01108 Cal. App.2d 303, 239 P.2d 48 (1951).

02 See Part I, 43 CaIIF. L. Rev. at 617-20. 
basis of the protection by express disclaimer of liability. In this section, however, the situations which do not seem to fit into other such categories will be examined. When a steamship company furnishes slings to a contractor for loading its ships, the contractor's employees inspect them, reject some, and then are injured by the failure of one that was accepted, it is commonly recognized that the victims had assumed that risk..$^{03}$ Similarly, one must expect to find chicken bones in chicken dishes served at a restaurant, and injury from such bones is not compensable at the expense of the restaurateur or clientele. ${ }^{94}$ Also, unreasonable use of the product by the plaintiff will prevent his recovery; the marketer is protected against liability for injury from such use.

(a) Where Plaintiff is Aware of the Defect. It is familiar contract law that recovery for breach of a conditional warranty requires proof of the fulfillment of the condition. Where serum is warranted to achieve immunity from cholera, and the buyer fails to use the minimum quantity of serum specified on the label or accompanying literature, he will fail to recover damages. $^{95}$ The same principle holds in tort law. A plaintiff will fail in negligence if defendant proves that he provided a clear warning of the danger and that plaintiff disregarded it. ${ }^{96}$ The marketer may also use as a defense the fact that the plaintiff personally discovered the defect but went ahead and unreasonably continued to use the product. With regard to food products, however, "the courts have been liberal in letting the consumer

83 McCall v. Pacific Mail S.S. Co., 123 Cal. 42, 55 Pac. 706 (1898).

94 Mix v. Ingersoll Candy Co., 6 Cal.2d 674, 59 P.2d 144 (1936); Lamb v. Hill, 112 Cal. App.2d 41, 245 P.2d 316 (1952) ; Silva v. F. W. Woolworth Co., 28 Cal. App.2d 649, 83 P.2d 76 (1938) (although the bone there apparently may have been in the dressing and not in the meat at all as served); Morris v. Pig'n Whistle \&c. Inc., 79 Ga. App. 369, 53 S.E.2d 718 (1949); Goodwin v. Country Club of Peoria, 323 Ill. App. 1, 54 N.E.2d 612 (1944); Brown v. Nebiker, 229 Iowa 1223, 296 N.W. 366 (1941). See MELICK, THE SAIE OF FOOD ANd DRINK 52-57 (1936); Dickerson, Products LIABIITY AND THE FOOd CoNsumer 183-90 (1951). Distinguish, however; a piece of bone in chicken soup containing barley and vegetables. "[T]he question is not whether the substance may have been natural or proper at some time in the early stages of preparation of this kind of soup, but whether the presence of such substance, if it is harunful and makes the food unfit for human consumption, is natural and ordinarily expected to be in the final product ...." Wood v. Waldorf System, 79 R.I. 1, 6, 83 A.2d 90, 93 (1951) (recovery denied). Contra, Paolinelli v. Dainty Foods Mfg., Inc., 322 Ill. App. 586, 54 N.E.2d 759 (1944) (chicken bone in chicken noodle soup). Recovery was allowed in Gimenez v. Great Atlantic \& Pacific T. Co., 264 N.Y. 390, 191 N.E. 27 (1934), for injury froin crystallized natural salt from the juices of canned crabs, but the question of assumption of risk (or reasonable fitness for human consumption) was not discussed.

95 C. Lomori and Son v. Globe Laboratories, 35 Cal. App.2d 248, 95 P.2d 173 (1939).

96 Tingey v. E. F. Houghton \& Co., 30 Cal.2d 97, 179 P.2d 807 (1947) ; Crochet v. DeLuca, 53 So.2d 203 (La. App. 1951); Richardson v. DeLuca, 53 So.2d 199 (La. App. 1951). 
continue to eat even after he discovers distasteful characteristics." ${ }^{97}$ An unreasonable attempt to remedy the defect will also bar the plaintiff. ${ }^{98}$ In warranty actions injury from such unreasonable use is called an avoidable consequence for which the warrantor is not liable. ${ }^{99}$ In negligence the injury is called unforeseeable. The area of reasonableness of use is narrower where there is knowledge of the defect, but knowledge of itself does not preclude further use being reasonable.

(b) Where Plaintiff is Ignorant of the Defect. The manufacturer is not protected against liability for injury resulting in the normal, ordinarily accepted use of his product. He cannot claim immunity from responsibility for a carelessly constructed chair by saying that the injury occurred while plaintiff was standing on the chair, and that the chair was meant to sit on, not to stand upon. ${ }^{100}$ It is common practice to stand upon chairs to reach high cupboards. It may be unreasonable, on the other hand, to stir decorating powder with one's finger. ${ }^{101}$ Not even if the plaintiff's use is found to be negligent is the marketer's liability necessarily denied. If the negligent use of the product is to be expected and is within the area of reasonable prevision, then liability is not displaced. The plaintiff's act is a concurring, not a superseding, cause, the courts will say. ${ }^{102}$

There are, however, many situations where the marketer is protected in spite of plaintiff's ignorance of the defect. Sometimes the court calls this

07 Dicrerson, Products Liabitity and the Food Consumare 78 (1951), and see cases there cited. See also Friedman v. Beck, 250 App. Div. 87, 293 N.Y. Supp. 649 (1937) (no recovery for canned lobster eaten after noticing it smelled and tasted peculiar); Walker v. Packing Co., 220 N.C. 158, 16 S.E.2d 668 (1941) (no recovery for lard that smelled like carrion); Saddlemire v. Coca Cola Co. of Canada, [1941] Ont. W.N. 392, 4 D.L.R. 614. Adequate cooking, lowever, is required. See Leonardi v. Provision Co., 143 Ohio St. 623, 56 N.E.2d 232 (1941) (a trichinosis case); DrCKERSON, supre at 190-211.

Cases of unreasonable use after discovery are: Gutelius v. General Electric Co., $37 \mathrm{Cal}$. App.2d 455, 99 P.2d 682 (1940) (plaintiff continued to use a wringer on which the shifter lever kept failing); Tourte v. Horton Mfg. Co., 108 Cal. App. 22, 290 Pac. 919 (1930) (plaintiff knew the safety device of a wringer needed oil but continued to use it without oil); Allen v. Talbot, 6 P.C.L.J. 980 (Super. St. San Francisco 1881) (plaintiff put lis face over the liole of a fuse that delayed fire, and the fuse lad been kept several months in a damp tunnel).

08 Youtz v. Thompson Tire Co., 46 Cal. App.2d 672, 116 P.2d 636 (1941) (plaintiff helped to hammer flush the ends of a collapsible rim of a tire repaired by defendant); Galvin v. Lynch, 137 Misc. 126, 241 N.Y. Supp. 479 (1930) (plaintiff attempted to adjust a vacuum cleaner).

99 Cf. Eisenbach v. Gimbel Bros., Inc., 281 N.Y. 474, 24 N.E.2d 131 (1939), where, lowever, the action was dismissed without an award of nominal damages.

100 Phillips v. Ogle Aluminum Furniture, 106 Cal. App.2d 650, 235 P.2d 857 (1951).

${ }^{101}$ Schfranek v. Benjamin Moore \& Co., 54 F.2d 76, 77 (S.D.N.Y. 1931), where an ultimate purchaser failed against the manufacturer because the product "does not, in order tliat the ultimate user may get the benefit of it, lave to be used in any way in which the alleged defect would probably cause injury ...." There was glass in with the powder. The decision seems questionable.

${ }_{102}$ Northwestern Nat'l Ins. Co. v. Rogers Etc. Foundry, 73 Cal. App.2d 442, 166 P.2d 401 (1946). 
contributory negligence (or avoidable consequence). Plaintiff's careless lighting of a match near paint warranted nonexplosive by defendant will exclude his recovery. ${ }^{103}$ The extent of marketer protection may possibly contract, however, as the concept of "reasonable use" receives more conscious interpretation. In Cliff v. California Spray Chemical Co ${ }^{104}$ plaintiff lost a suit for injury when the plug of a drum of spraying solution was thrown out of its hole and his eye was hit by a stream of sulphur solution. The record showed that the reason why the liquid spurted out was that the drum was tilted. The act of tilting intervened to cause the spurt of liquid. It could well be asked whether the risk of such apparently common "misuse" of a product should not be spread among the public. It must be impossible under real conditions to keep drums of liquid absolutely level in open fields, just as it is recognized as impossible to safeguard bottles against every jolt and knock during transportation. ${ }^{105}$ The concept of "reasonable" is a variable factor here and is beginning to lose its moral character and acquire a statistical foundation. ${ }^{106}$ If a certain procedure is common, is known to exist, and is accepted by society, then it is "reasonable," and society implicitly submits to sharing the risk of damage from it.

\section{Typical Injury}

It must, of course, be determined what constitutes compensable "injury." Damage to property and to pecuniary interests are straightforward, but the area of protection accorded to personal injury is more uncertain. Shight physical injury is enough. Mere nausea and an upset stomach which caused plaintiff neither to leave work nor to seek medical attention was enough in one case to recover $\$ 301$ damages. ${ }^{107}$ Plaintiff had taken a swallow of Coca Cola from a bottle which contained a dead mouse. More difficult, in many instances, is the task of proving that the injury (which may

103 Fidelity Etc. Co. v. Paraffine Paint Co., 188 Cal. 184, 204 Pac. 1076 (1922). Contributory negligence was also successful as a defense in Cunninglam v. Coca Cola Bottling Co., 87 Cal. App.2d 106, 198 P.2d 333 (1948).

10483 Cal. App. 424, 257 Pac. 99 (1927).

105 See text supra at notes 20-23. It would appear that kneeling on wet ready-mix cement is unreasonable use, Dalton v. Pioneer Sand \& Gravel Co., 37 Wasl.2d 946, 227 P.2d 173 (1951) ; and so is wearing a cocktail robe for cooking dinner in the kitclien, Ringstad v. I. Magnin \& Co., 39 Wasll.2d 923, 239 P.2d 848 (1952). In this context, Borg-Warner Corporation v. Heine, 128 F.2d 657 (6th Cir. 1942), loolding that attempted repair on the part of plaintiff employee of the retailer of a refrigerator was not "normal" use and giving no recovery from the manufacturer, seems clearly wrong.

100 Injury to a thief or other "illegitimate" user might be considered unreasonable on policy grounds (or the duty and liability extend only to "legitimate" users). See NEw YorK Law Revision Comanission Report 462 (1943).

107 Moss v. Coca Cola Bottling Co., 103 Cal. App.2d 380, 229 P.2d 802 (1951). 
be conceded) was in fact caused by the defect (which may be conceded) ${ }^{108}$ There are two kinds of personal injury which have created much controversy and which deserve special discussion.

(a) Shock. In Dryden v. Continental Baking Co. ${ }^{109}$ plaintiff could not prove that she had swallowed any portion of the bread containing glass particles similar to those found in the uneaten part. No glass was found in her stomach. From the nervous shock which followed her discovery of the glass, however, there resulted psychological inability to eat for some time producing indigestion and intestinal irritation. The supreme court allowed recovery, and stated the principle in another case: ${ }^{110}$

[I]n this state definite disturbances of the nervous system caused by nental shock, excitement, and so on, are classed as physical mjuries and are recognized elenıents of damage.

Physical injuries which result from mental shock are clearly elements of damage, ${ }^{111}$ but beyond that, mental shock itself may be a source of damages if it has a definite harmful effect on the nervous system. In a case where plaintiff drank a bottle of Coca Cola containing a cleaning brush and suffered shock without harmful physical results, recovery was granted, and the court said:112

We thimk that a court nuay well take judicial notice that even a normal person in seeing a disgusting looking object in a bottle fron which he has just drunk may and often will suffer intense nausea which may produce more serious results. Also one may recover for injury resulting from mental shock in such cases.

It is questionable, however, whether recovery would be had for shock upon merely seeing the object without drinking any of the beverage or eating any of the food containing it. ${ }^{113}$ This is a point which remains unsettled

${ }^{108}$ See, e.g., Alma Canning Co. v. Rorie, 216 Ark. 444, 226 S.W.2d 64 (1950) (worm in can of beans); Foley v. Coca Cola Bottling Co., 215 S.W.2d 314 (Mo. App. 1948) (tack in Coca Cola causing stomacb ulcer); Hankins v. Coca Cola Bottling Co., 151 Tex. 303, 249 S.W.2d 1008 (1952) (did explosion of bottle cause softening of knee tissue?).

10911 Cal.2d 33, 77 P.2d 833 (1938).

110 Taylor v. Pole, 16 Cal.2d 668, 671, 107 P.2d 614, 616 (1940).

111 "Fright alone is not an 'mjury' that may be the basis of a claim for damages, but physical injury due to fright is compensable." Cook v. Maier, 33 Cal. App.2d 581, 584, 92 P.2d 434, 436 (1939). See also Clough v. Steen, 3 Cal. App.2d 392, 39 P.2d 889 (1934).

112 Medeiros v. Coca Cola Bottling Co., 57 Cal. App.2d 707, 714, 135 P.2d 676, 680 (1943).

113 In Sapiente v. Waltuch, 127 Conn. 224, 15 A.2d 417 (1940), plaintiff testified that she became ill from eating adulterated macaroni, but her doctor testified that she became ill from merely seeing it. The court held that the jury was entitled to believe plaintiff's testimony as against her doctor's. In Cushimg Coca Cola Bottling Co. v. Francis, 206 Okla. 553, 245 P.2d 84 (1952), plaintiff took a swallow, remarked that the beverage did not taste right, took another bottle and drank from that, and only when his attention was called to the presence of a mouse in the first bottle did he become nauseated and vomit. He subsequently alleged mental anguish. 
in California. It is interesting to find that medical investigation tends to indicate that very few foreign substances in food are in fact harmful, and that the injury is very often psychologically induced..$^{114}$ This, of course, does not affect the case for compensating consumers for injuries which are not faked but which might have been avoided by better public medical education.

(b) Allergy. The defendant often alleges, by way of defense, that plaintiff was allergic to some constituent of the product, especially in cosmetic cases, and that it was this allergy that was the proximate cause of the injury rather than any defect in the product. ${ }^{115}$ This begs the question, of course, as to when a product is defective. One must be careful to ask exactly what is meant by "allergy" in this context. It is a misleading word. A recent writer puts it in these words: ${ }^{116}$

[T] he allergic diseases are diseases to which a certain portion of the population is susceptible, just as a certain portion of the population, due to its particular state of resistance, is susceptible to any particular infectious disease.

The portion which is at any given moment affected by some hypersensitivity to various irritants is, however, small. The incidence of some of the common allergies is reckoned at between five and ten per cent of the total population. ${ }^{117}$ Clearly, it is no defense to a personal injury claim for pneumonia caused by a defective water heater that someone else more strong and resistant than plaintiff would not (or in similar circumstances actually did not) contract pneumonia, nor that only three per cent of the total population of the country was, at the time of suit, infected with pneumonia.11s

The court held that "he had no mental effect from a physical reaction," and reversed judgment for the plaintiff. It seems indefensible to hold vomiting as a result of seeing the foreign object after unconsciously eating or drinking part of the affected product anything less than a physical reaction, but since plaintiff offered no expert inedical evidence of the cause or nature of his injuries, there is a smell of fraud about the case. Possibly cases of foreign matter which is obnoxious (cockroaches, slime, etc.) should receive more favorable treatment than cases of articles such as nails, cork, etc.

114 See Guiher \& Morris, Handling Food Products Liability Cases, 1 Food Druo Cosm. L.J. 109, 128-30 (1946), and citations. It does not have to be proved that the foreign substance was actually poisonous. Sweeney v. Cain, 243 S.W.2d 874 (Tex. Civ. App. 1951).

115 Antowill v. Friedmann, 197 App. Div. 230, 188 N.Y. Supp. 777 (1921).

116 Horowitz, Allergy of the Plaintiff as a Defense in Actions Based Upon Breach of Implied Warranty of Quality, 24 So. CaLrF. L. Rev. 221, 226 (1951). See also Stanfill, Investigation of Cosmetic Injuries, 7 Food Druo Cosar. L.J. 654 (1952) ; Dickerson, Products IIabitITY AND THE FOOD CoNsuMrer 211-30 (1951) ; Note, 16 Austr. L.J. 19 (1942); and the stimulating study of Barasch, Allergies and the Law, 10 BroozLXN L. REv. 363 (1941).

117 See Comment, 49 Mrcr. L. Rev. 253 (1950), and authorities (medical) there cited.

118 McCubbin v. Hastings, 27 La. Ann. 713 (1875) (yellow fever); Delta Nehi Bottling Co. v. Lucas, 184 Miss. 693, 185 So. 561 (1939) (condition of pyelitis did not prevent recovery for nausea); Geisness v. Scow Bay Packing Co., 16 Wash.2d 1, 132 P.2d 740 (1942). The injuries, on the other hand, must be reasonably expectable for the test of foreseeabihty and causation. Poplar v. Bourjois Inc., 272 App. Div. 74, 69 N.Y.S.2d 252 (1947), aff'd on other grounds, 298 N.Y. 62, 80 N.E.2d 334 (1498) (unusual imfection of hemolytic streptococcus) 
The allergic diseases are lesser known but no more stigmatic than those for which recovery is undisputed. They are harder to prove, however, and there is difficulty in distinguishing them from mere personal peculiarities. Plaintiff must bring expert medical evidence that other persons are similarly affected by this constituent. Significantly, plaintiff failed to do this in the only two cases found on this topic in California, Zager v. $F$.W.Woolworth Co. ${ }^{119}$ and Briggs v. National Industries, Inc., ${ }^{120}$ and was denied recovery in both. Similar failure was present in practically all of the out-ofstate cases denying recovery. ${ }^{121} \mathrm{~A}$ case in which such evidence was offered would be novae impressionis in this state, and it is submitted that recovery should there be allowed. In other words, it may not be enougl for the marketer to bring in evidence that other consumers or users have used the product without harmful results if plaintiff proves that in fact some people are injured by it.

That the great majority of persons are safe from the particular danger concealed in the article sold, or that few injuries in fact result from its use, does not militate against this principle [of liability for defective products] when the certain fact of imminent danger to a percentage is established. ${ }^{122}$

In the case from which the above language was quoted, the manufacturer knew that furs were injurious to "some persons." ${ }^{223}$ Other cases in which recovery was allowed have had testimony that four to five per cent of users would be harmed, ${ }^{124}$ that "quite a percentage of people" were sensitive to a

11030 Cal. App. 2d 324, 86 P.2d 389 (1939) (warranty action for freckle cream failed; plaintiff's "constitutional composition was the proximate cause of the dermatitis").

12092 Cal. App.2d 542, 207 P.2d 110 (1949) (recovery from retailer and manufacturer of hair-wave preparation denied).

121 Franke's, Inc. v. Bennett, 201 Ark. 649, 146 S.W.2d 163 (1941); Cicarelli v. Lipshetz, 8 Conn. Supp. 526 (1940) (lipstick); Stanton v. Sears Roebuck \& Co., 312 Ill. App. 496, 38 N.E.2d 801 (1942) (rayon dress) ; Ross v. Porteous, Mitchell \& Braun Co., 136 Me. 118, 3 A.2d 650 (1939) (dress shield) ; Longo v. The Touraine Stores, Inc., 319 Mass. 727, 66 N.E.2d 792 (1946); Graham v. Jordan Marsh Co., 319 Mass. 690, 67 N.E.2d 404 (1946) (cold cream); Payne v. R. H. White Co., 314 Mass. 63, 49 N.E.2d 425 (1943) (dress); Bradt v. Hollaway, 242 Mass. 446, 136 N.E. 254 (1922) (fur); Gould v. Slater Woolen Co., 147 Mass. 315, 17 N.E. 531 (1888) (dyed cloth); Worley v. Procter \& Gamble Mfg. Co., 253 S.W.2d 532 (Mo. App. 1952) (washing powder) ; Drake v. Herrman, 261 N.Y. 414, 185 N.E. 685 (1933) (hair coloring product); Karr v. Inecto, Inc., 247 N.Y. 360, 160 N.E. 398 (1928) ; Kinkead v. Lysol, Inc., 250 App. Div. 832 (N.Y.1937) (disinfectant); Cahill v. Inecto, Inc., 208 App. Div. 191, 203 N.Y.Supp. 1 (1924); Antowill v. Friedmann, 197 App. Div. 230, 188 N.X.Supp. 777 (1921) (X-ray); Singer v. Oken, 193 Misc. 1058, 87 N.Y.S.2d 686 (1949); Cleary v. Maris Co., 173 Misc. 954, 19 N.Y.S.2d 38 (1940) (lead nipple shield); Barrett v. S. S. Kresge Co., $144 \mathrm{~Pa}$. Super. 516, 19 A.2d 502 (1941) (cotton dress); Walstrom Optical Co. v. Miller, 59 S.W.2d 895 (Ter. Civ. App. 1933); Bennett v. Pilot Products Co., 235 P.2d 525 (Utah 1951); Griffiths v. Peter Conway, Ltd., [1939] 1 All E.R. 685; Levi v. Colgate-Palmolive Pty. Ltd., 41 New So. W. St. 48,58 New So. W.W.N. 63 (1941).

122 Gerkin v. Brown \& Sehler Co., 177 Mich. 45, 61, 143 N.W. 48, 53 (1913) (dyed furs). 123 Accord, Bianchi v. Denholm \& McKay Co., 302 Mass. 469, 19 N.E.2d 697 (1939) (face powder).

124 Zirpola v. Adam Hat Stores, Inc., 122 N.J.L. 21, 4 A.2d 73 (1939) (aniline dye in hat). 
constituent and that this "was known to be common amongst the trade,"125 and that three witnesses suffered similar irritation from the product. ${ }^{120}$ Actual knowledge of the particular user's sensitivity will, of course, impose a duty on the supplier to warn her, ${ }^{127}$ and actual knowledge of the harmful propensity of a particular constituent would make the manufacturer liable. ${ }^{128}$ Going further, it seems that the point has been reached at which the manufacturer of cosmetics, or the food processor using new chemical additives, should be required to take expert medical advice and should be liable if it is generally acknowledged in the medical profession that the use of such chemicals will affect a significant number of people. The size of the percentage will have to be left to charismatic experience, but it is interesting to find a judge in a concurring opinion in a recent Utah case ${ }^{120}$ expressing the view that foreseeability alone cannot be a proper test here, since if it were known scientifically that 1 in 1000 would suffer, then it would be foreseeable that that one would be hurt, and the result would be to overburden business. In fact, it seems doubtful that any reasonable business would be crippled by the expense of insurance against liability for such a specified risk.

Of course, knowledge on the consumer's part must be presumed with some of the better-known sources of allergic injury such as strawberries. The chief care must be with new chemical ingredients in cosmetics and food. The marketer must be able to protect himself by charging the consumer with knowledge of the danger by accurate labeling and predisposition notices. ${ }^{130}$ The problem of disclaimer is acute here. A warning con-

125 Taylor v. Newcomb Baking Co., 317 Mass. 609, 59 N.E.2d 293 (1945) (soap with trisodium phosphate base).

126 Carter v. Yardley \& Co., Ltd., 319 Mass. 92, 64 N.E.2d 693 (1946) (perfume).

127 Arnold v. May Department Stores Co., 337 Mo. 727, 85 S.W.2d 748 (1935) (plaintiff told hairdresser that she had had trouble ten years before with hairdying). Cf. Reynolds v. Sun Ray Drug Co., 135 N.J.L. 475, 52 A.2d 666 (1947) (lipstick).

128 Gerkin v. Brown \& Sehler Co., 177 Mich. 45, 143 N.W. 48 (1913). See generally Note, 5 BAYLOR L. REv. 363 (1952).

120 Bennett v. Pilot Products Co., 235 P.2d 525 (Utah 1951). Barasch, Allergies and the Law, 10 BrookzyN L. REv. 363, 368 (1941), suggests that hability in warranty, as distinct from negligence, should not depend on reasonable expectation of harm. It is submitted that whatever the form of action, the hine drawn, and its policy basis, are identical. Recovery in case of allergy which affected 1 in 8,000 was denied (on the ground of no proximate cause) in Crean v. Inecto, Inc., 99 N.Y.L.J. 2283 (1938), cited by DickERson, Products LIAbILITY AND THE FOOD CONSUMER 221 n.2 (1951). Although apparently 1 in 200 or 300 are hypersensitive to X-ray treatment, Antowill v. Friedmann, 197 App. Div. 230, 232, 188 N.Y. Supp. 777, 778 (1921), all of the X-ray cases failed. See, e.g., Hamilton v. Harris, 223 S.W. 533 (Tex. Civ. App. 1920).

130 See Horowitz, Allergy of the Plaintiff as a Defense in Actions Based Upon Breacli of Implied Warranty of Quality, 24 So. CaLIF. L. Rev. 221 (1951); Drckerson, Products LiabLITY AND THE Food Consumar 224-30 (1951). The Federal Food, Drug, and Cosmetic Act, 52 STAT. 1040 (1938), 21 U.S.C. $\$ \S 301-92,(1952)$, requires certain drugs to carry the name 
sisting of notice of the use of a certain chemical should not protect the manufacturer where the plaintiff is justifiably ignorant of his sensitiveness to that chemical. Perhaps the only ultimate protection will lie in directing local tests, e.g., on the arm in the case of cosmetics, and in the case of foodstuffs, in requiring medical advice and consultation on the manufacturer's part. Probably the manufacturer will have to be allowed his "first bite" in the case of new ingredients pronounced safe by the experts. At any rate, the general proposition still remains that if a small portion of the public will in fact be harmed by a product, there is no reason why one of that class should recover if it is encephalitis that results, but fail if it is allergic dermatitis. ${ }^{131}$ Of course, there may be an express warranty covering the type of injury under discussion. ${ }^{132}$

II

\section{DISCLAIMER OF IIABILITY}

It is possible for the enterprise to achieve protection, even against typical risks, by expressly disclaiming hability. A disclaimer is prima facie operative under the Uniform Sales Act ${ }^{133}$ and in orthodox contract law to exclude liability on a warranty. The commonest provision is the "merger" clause, which states that the written contract contains all the agreements between the parties and that no representations not specifically included therein shall be binding. ${ }^{134}$ A clause denying responsibility for the effectiveness of a product has also been held good protection, ${ }^{\mathbf{1 3 5}}$ and even an oral

of their active ingredients, partly to enable users to avoid those drugs to which they are allergic. See the discussion of this point in Comment, 49 MICH. L. REv. 253, 259-61 (1950). Predisposition notices are enclosed with soine products. See Barasch, Allergies and the Law, 10 BrookLYN L. Rev. 363, 375 (1941), and references there listed. Cf. Bundy v. Ey-Teb, Inc., 160 Misc. 325, 289 N.Y. Supp. 905 (1935).

131 The saine degree of constructive notice should be allowed.

132 McLachlan v. Wil. Dry Goods Co., 41 Del. (2 Ter.) 378, 22 A.2d 851 (1941) (statenent that dress contained nothing that would cause injury to plaintiff).

133 See Part I, 43 CAIIF. L. REv. at 617.

134 S. F. Bowser \& Co. v. Independent Dye House, 276 Mass. 289, 177 N.E. 268 (1931); Rockwood \& Co. v. Parrott \& Co., 142 Ore. 261, 19 P.2d 423 (1933) (a food case where the warranty by a manufacturer to a retailer was thus negatived); Valley Refrigeration Co. v. Lange Co., 242 Wis. 466, 8 N.W.2d 294 (1943) (express oral warranty notwithstanding). Contra, Kanaster v. Berry, 212 Ark. 430, 206 S.W.2d 13 (1947); Bekkevold v. Potts, 173 Minn. 87, 216 N.W. 790 (1927) ; Davies v. Motor Radio Co., 236 S.W.2d 409 (Mo. App. 1951) ; Myer v. Packard Co., 106 Ohio St. 328, 140 N.E. 118 (1922); Hobart Mfg. Co. v. Rodziewicz, $125 \mathrm{~Pa}$. Super. 240, 189 Atl. 580 (1937). See Prosser, The Implied Warranty of Merchantable Quality, 27 Mins. L. REv. 117, 157-67 (1943), and Note, 23 MINN. L. REv. 784 (1939), for discussion of the policy of the courts in interpreting and limiting the operation of disclainers in the light of allocation of contract risks. See also Morrow, Warranty of Quality: A Comparative Survey, 14 Tul. L. Rev. 529, 570 (1940); Dickerson, Products LiabIlity aNd THE Food Consumer 97 n.10 (1951); New YORR Revision Cornorission Reporss 465-66 (1943).

135 Buckley v. Shell Chemical Co., 32 Cal. App.2d 209, 89 P.2d 453 (1939). This was the case where handwritten across the disclaimer was "guaranteed to be Black Diamond" and 
statement to that effect has succeeded.$^{136}$ The striking out of an original, printed, express warranty may have the same effect, ${ }^{137}$ and, of course, so may a clear statement that the seller expressly refuses to warrant. ${ }^{138}$ It is possible to achieve protection by merely incorporating in the contract a clause that no implied warranties are made. ${ }^{130}$ It has been held that lack of notice on the part of the buyer is no bar to the effectiveness of the disclaimer if the buyer should have been aware of it under the circumstances, fraud and concealment always apart. ${ }^{140}$ As was said in a recent New York case, the buyers read the bill containing the disclaimer clause, and if they did not actually see that clause, "they had the plain opportunity to do so."141

It is true that on orthodox liberty of contract theory it is open to both parties to agree upon what they please. ${ }^{142}$ This assumes that both parties liave reasonably equal bargaining power. The assumption and the conclusion have been criticized in sucl situations as contracts of fare between passengers and railroad compamies. ${ }^{143}$ Equality of bargaining power cannot be claimed in a negotiation between a private citizen and a large corporation, particularly if the latter (either alone, or in combination with other large corporations) monopolizes the commodity under negotiation, whether it be a ride on a train or a can of beans. There is evidence that such criticism of the traditional validity of disclaimer has made itself felt in the field under discussion.

In the first place, it is often stated that a disclaimer will be construed against the seller, and this rule is a tabula in naufragio for hard cases. It is

instead another worthless brand was supplied. Hall v. Mosteller, 245 S.W.2d 338 (Tex. Civ. App. 1951). In the special case of seeds, bowever, evidence of a custom of nonwarranty has been accepted. Miller v. Germain Seed Etc. Co., 193 Cal. 62, 222 Pac. 817 (1924) ; Hoover v. Utah Nursery Co., 79 Utah 12, 7 P.2d 270 (1932). Contra, Rocky Mountain Seed Co. v. Knorr, 92 Colo. 320, 20 P.2d 304 (1933).

136 Alex J. Mandl, Inc. v. San Roman, 170 F.2d 839 (7th Cir. 1948).

137 Sutter v. Associated Seed Growers, Inc., 31 Cal. App.2d 543, 88 P.2d 144 (1939).

138 Couts v. Sperry Flour Co., 85 Cal. App. 156, 259 Pac. 108 (1927).

139 Traylor Eng. Co. v. Nat. Container Corp., 45 Del. (6 Ter.) 143, 70 A.2d 9 (1949); Gibson v. Calif. Spray-Chemical Corp., 29 Wash.2d 611, 188 P.2d 316 (1948). To the same effect is an "as is" or "as is no recourse" clause: Garofalo Co. v. St. Mary's Packing Co., 339 III. App. 412, 90 N.E.2d 292 (1950); Thrash v. U-Drive-It Co., 158 Olio St. 465, 110 N.E.2d 419 (1953). Contra, Kulilmann v. Purpera, 33 So.2d 84 (La. App. 1947). A statement in the contract that the buyer expressly waives all claims for damages and all "provisions of law wherein and whereby it is required that any sum of money shall be repaid" waives impled warranties. Byrd v. Harry Somners Inc., 87 Ga. App. 663, 75 S.E.2d 287 (1953).

140 Kennedy v. Cornhusker Hybrid Co., 146 Neb. 230, 19 N.W.2d 51 (1945); Gibson v. Cahif. Spray-Cheunical Corp., 29 Wash.2d 611, 188 P.2d 316 (1948).

141 Finkelstein v. Ginsburg, 60 N.Y.S.2d 667 (1946).

142 The theoretical availability of disclaimer is the greatest weakness of the adoption of the "jumping warranty" as a solution of the products problem. See Dickerson, Products LIABIITY AND THE FOOd CONSUMER 97-110 (1951).

143 See generally Notes, 38 MICH. L. Rev. 1310 (1940), 22 MINN. L. REv. 107 (1937), 4 Mo. L. Rev. 55 (1939). Cf. Ehrenzweig, Adhesion Contracts in the Conflict of Laws, 53 Coruas. L. Rev. 1072, 1075 \& n.17 (1953). 
increasingly relied upon in the more recent cases. ${ }^{144}$ The argument is made that the implied warranty is imposed by law outside of any "meeting of two minds," and that only express disclaimer of implied warranties will defeat them. ${ }^{145}$ " $[\mathrm{I}] \mathrm{f}$ it had been intended to exclude such a warranty, it was incumbent upon the parties so to state in the contract." 146 The classic example of drafting skill in due observation of this precaution is contained in the English case of L'Estrange v. F. Graucob Ltd. ${ }^{147}$ where the written contract excluded "any express or implied condition, statement or warranty, statutory or otherwise, not stated herein ...." Obviously the satisfactoriness of this reasoning is proportionate to the laziness, sheerly incompetent draftsmanship or eye for good will and public relations of individual sellers.

A second factor limiting the disclaimer is the requirement of fair notice to the buyer. It is no defense if the buyer excusably does not read the disclaimer because it is in fine print, ${ }^{148}$ in an obscure place, ${ }^{149}$ or not brought to his attention until after the contract is completed. ${ }^{150}$ Thirdly, performance of the contract is still required. Disclaimer is no good if the seller supplies something that is unable to perform its intended purpose; that would be a "failure of consideration" and a "breach of the contract itself." 151 In the fourth place, categorical exceptions have been made for specific products. This has been accomplished by legislation. There is a North Dakota statute, for example, which specifies that a disclaimer will not prevent rescission of the contract in the sale of harvesting machinery. ${ }^{162}$ There is a growing demand by writers for generalizing or extending

144 Burr v. Sherwin Williams Co., 42 Cal.2d 682, 268 P.2d 1041 (1954); McPeak v. Boker, 236 Minn. 420, 53 N.W.2d 130 (1952) ("represented as being in good physical-mechanical condition but not guaranteed in any way"); Lunbrazo v. Woodruff, 229 App. Div. 407, 242 N.Y. Supp. 335 (1930); Elliott-Lewis Corp. v. York-Shipley, Inc., 372 Pa. 346, 94 A.2d 47 (1953).

145 Bekkevold v. Potts, 173 Minn. 87, 216 N.W. 790 (1927).

146 Buchanan v. Dugan, 82 A.2d 911, 913 (D.C. Munic. Ct. App. 1951).

147 [1934] 2 K.B. 394. The precaution was also observed in, e.g., Sears, Roebuck \& Co. v. Lea, 198 F.2d 1012 (6th Cir. 1952). See also Wade v. Chariot Trailer Co., 331 Mich. 576, 50 N.W.2d 162 (1951); Gleckler v. Russeks Fifth Avenue, Inc., 276 App. Div. 751, 92 N.Y. S.2d 607 (1949) (no opinion), reversing 84 N.Y.S.2d 813 (1948); Deere and W. Co. v. Moch, 71 N.D. 649, 3 N.W.2d 471 (1942).

148 Woodworth v. Rice Brothers Co., 110 Misc. 158, 179 N.Y. Supp. 722 (1920), aff'd, 193 App. Div. 971, 184 N.Y. Supp. 958 (1920).

148 Linn v. Radio Center Dehicatessen, Inc., 169 Misc. 879, 9 N.Y.S.2d 110 (1939). Cf. Myers v. Land, $314 \mathrm{Ky} .514,518,235$ S.W.2d 988, 990 (1951), where the disclaimer was "found in a long and formidable document prepared by the seller and ... doubtless unnoticed or its import uncomprchended by the buyer."

160 Ward v. Valker, 44 N.D. 598, 176 N.W. 129 (1920).

151 Myers v. Land, 314 Ky. 514, 235 S.W.2d 988 (1951) (concrete block manufacturing machme).

102 N. D. Rev. CoDE $\S 51-0707$ (1943). Similar treatment of sale of seeds is urged in Note, 1948 N. D. BAR BRIEFS 151. 
the statutory protection of the products consumer. ${ }^{153}$ In one area this is being achieved by judicial development. It has been held that a disclaimer is inoperative in the sale of food for consumption. As was said in the leading case, Linn v. Radio Center Delicatessen, Inc.: ${ }^{154}$

[I] $t$ is against natural justice and good morals to permit an individual or corporation to manufacture food containing dangerous foreign substances and to escape the consequences of his acts by a disclaimer.

It should be noted that the inequality of bargaining power argument does not apply to a contract between, for example, a large manufacturing company and a large retailing corporation. Many of the cases where disclaimer has been held effective are cases of this sort. There is nothing immoral or impolitic in allowing experienced marketers with insurance protection to juggle the risk of defectiveness between themselves as they wish. It is when a single individual is claiming compensation for personal injuries that other factors enter. In the Linn case, for example, the disclaimer was contamed in a contract between manufacturer and retailer, but the suit was by a consumer against the retailer, the manufacturer being impleaded as third party defendant. The latter's liability to the consumer was dependent, therefore, upon his liability to the retailer. The disclaimer was held inoperative. The opposite conclusion was reached in Rockwood \& Co. v. Parrott \& $\mathrm{Co}^{155}$ and in Garofalo Co. v. St. Mary's Packing Co. ${ }^{150}$ where the parties to the suits were the manufacturing corporation and the retailing corporation respectively. It is suggested that equality of bargainmg power is a very real factor in the decisions upholding disclaimers, and that it should openly be recognized as such. It comes to this: a disclaimer protects a manufacturer against claims by his corporate buyer where the loss is financial, i.e., where the defect is discovered before it causes personal injury. It does not protect him against claims by injured consumers, or by his corporate buyer who impleads him in a suit by the consumer (or, semble, has paid judgment damages to the consumer in a separate action). In other words, the disclaimer should operate strictly within its sale context, as controlling the financial risk of unmerchantability between the negotiating parties, but should have no effect upon the liability of the parties in tort for bodily injury caused by the product sold. It is not contended that this is presently

153 Bogert \& Fink, Business Practice Regarding Warranties in the Sale of Goods, 25 Irx. L. Rev. 400, 413 (1930) ; Comment, 57 YaIE L.J. 1389, 1401-04 (1948); Notes, 31 TEX. L. REv. 223 (1952), 1 VAND. L. REv. 467 (1948).

154169 Misc. 879, 880-81, 9 N.Y.S.2d 110, 112 (1939). Contra, Rockwood \& Co. v. Parrott \& Co., 142 Ore. 261,19 P.2d 423 (1933). The Linn case is weakened by the fact that the buyer had no actual notice of the disclaimer (which was printed alone on the back of an invoice). See American Hoist \& Derrick Co. v. Frey, 127 La. 183, 53 So. 486 (1910).

155142 Ore. 261, 19 P.2d 423 (1933).

$15 B 339$ IIl. App. 412, 90 N.E.2d 292 (1950). 
the law, but it is submitted that it is a desirable direction for the law to take, and that the facility with which the courts find excuses to annul the disclaimer when they are faced with a personal injury is evidence that such is the direction which the law is in fact taking.

Apparently there is no public policy against contracting against neghgence liability. Certainly this is true in merchant sales. ${ }^{157}$ Such a disclaimer, like the ones so far discussed, can only operate, lowever, within a contract, and is not ávailable against the third party. The effect of a printed warning placed on the label of a product or in literature which is brouglit to the ultiniate consumer's or user's attention may be considered as equivalent to at least partial disclaimer, operating outside the contract. Liability for consequential damages, ${ }^{168}$ or for breakdown of the product after a certain period of time ${ }^{159}$ or for the results of not using the product in the prescribed way ${ }^{160}$ may be excluded in this way. Whether a warning would always exempt a manufacturer is a difficult policy question. Perhaps it should only protect him where a warning is the only practicable alternative. The presence of trichinae, which is almost impossible for a meat packer to prevent, is an example. Instructions on the label of sausages that cooking for a certain time is necessary to make the product completely safe would be the only real way of protecting the public. The courts, however, are chary of allowing a warning to exempt the manufacturer. ${ }^{101}$ Warning, however, is a good educative, and thus preventative, measure and should at least permit the minimization of damages in these circumstances. "Judicial interpretation will have to determine where the line should be drawn between the warning of a special defect which would relieve the seller of his

157 In Charles Lachman Co. v. Hercules Powder Co., 79 F.Supp. 206 (E.D.Pa. 1948), the contract read, in part: "Buyer assumes all risk and liability whatsoever resulting from the use of such materials . ..." and the seller was lield relieved of all negligence liability to the buyer. There was, lowever, a clause preceding which ran: "seller makes no warranty of any kind, express or implied ...." Negligence liability was also limited m Shafer v. Reo Motors, 108 F.Supp. 659 (W.D. Pa. 1952).

158 Despatclı Oven Co. v. Rauenhorst, 229 Minn. 436, 40 N.W.2d 73 (1949).

160 Sears, Roebuck \& Co. v. Lea, 198 F.2d 1012 (6th Cir. 1952) (repairs within 5 years only).

160 C. Lomori and Son v. Globe Laboratories, 35 Cal. App.2d 248, 95 P.2d 173 (1939).

161 Leonardi v. Provision Co., 143 Ohio St. 623, 632, 56 N.E.2d 232, 237 (1944). See, lowever, Fredendall v. Abralıam \& Straus, Inc., 279 N.Y. 146, 18 N.E.2d 11 (1938); Rosenbusch v. Ambrosia Milk Corp., 181 App. Div. 97, 168 N.Y. Supp. 505 (1917) ; Maize v. Atlantic Ref. Co., 352 Pa. 51, 41 A.2d 850 (1945). See Note, 9 N.Y.U.L.Q. Rev. 360, 363 (1932). Cf. Cliff v. California Spray Chemical Co., 83 Cal. App. 424, 257 Pac. 99 (1927); Lewis v. Terry, 111 Cal. 39, 43 Pac. 398 (1896) ; Finney v. Curtis, 78 Cal. 498, 21 Pac. 120 (1889). RestateMIENT, TORTS $\$ 388$ (c) (1934), Iolds a supplier of potentially dangerous chattels to liability, inter alia, for failure "to exercise reasonable care to inform [those using it] of its dangerous condition or of the facts wlich make it likely to be so." See Dickerson, Products Liabitit AND THE FOOD CONSUMER 207-11 (1951), for an excellent elaboration of the duty to warn in trichinosis cases. 
liability, and the mere disclaimer of liability, which would presumably have to be expressly declared invalid by the statute."162

\section{CONCLUSION}

The courts are continually in the process of defining, for their own time and society, typicality of risk. Judges and juries have perpetually to decide, on behalf of the consuming public, what risks of the products enterprise are to be borne by the enterprise (and, in most cases, distributed among the public through price manipulation and insurance). Which risks does the public wish mutually to insure against, or rather, since the volonte générale is unsusceptible of empirical current ascertainment in every particular case, which risks should the public insure against? The establishment of a terminology-typicality of risk-does not make the day-to-day decisions any easier, and there is bound to be hesitancy and contradiction until a situation has emerged as recurrent and "typical" in the ordinary sense. ${ }^{163}$ Such a terminology would bring about an attendant clarification of policy objectives, and would assist the courts in coming to sensible decisions. Much of the earlier and contemporary case material indicates that the experimentation in characterizing risks as typical or not has been renarkably successful. It will assist students and the lay public, however, if it is made a hittle clearer exactly what it is that the courts are doing. More importantly, it may convince lawyers and lobbyists alike that the real place for enterprise protection is in the typicality problems, in the proof and causation questions, and not in the restriction of liability to the incidence of negligence and contract.

162 NEW YoRK LAW REviston COMOMISSTON REPORTS 461 (1943). The official draft of the Uniform Commercial Code supports this conclusion. Sections 2-316 and 2-317 require that exclusion or modification of the implied warranties must be in specific language, and that ambiguities shall be resolved against the seller (with the exception of "as is" or "with all faults" agreements, examination or refusal to examine by the buyer, and usage of trade). The remedies can be limited by liquidation or limitation of damages, or contractual modification of remedy. The seller may not, however, exclude or limit the operation of section 2-318, which extends the warranty to the buyer's household. The seller may exclude third parties from the contract wherever he may exclude the buyer, but may not discriminate between them.

163 See Marsh, Principle and Discretion in the Judicial Process, 68 L.Q. Rev. 226 (1952). Examples of the unpredictability of the charismatic factor are to be found in the text supra at notes 8-19. 